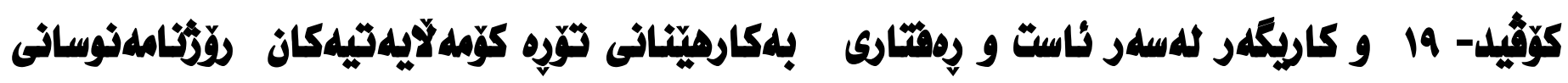 هلهيّمى كوردستان بلهنموونه
}

\section{نهزاكلةت حسيّن حلهمسلهيد}

بهشى راكهياندن، كؤليزى ز زانسته مروّايهتييهكان، زانكوى سليمانى، سليّمانى، هـريّمى كوردستان، عيّراق. nazakat.hamasaeed@univsul.edu.iq :يمهاءلْ

حلكيم عوسمان حهميد

بهشى بهبازاركردن و پِايوهندييه كثتييهكان، كؤليزى تهكنيكى كاركيّرى، زانكوى يُولهتهكنيكى سليمانى، سليمانى،

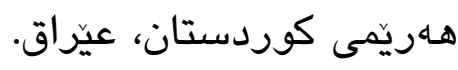
hakim.othman@spu.edu.iq ئيمايلْ

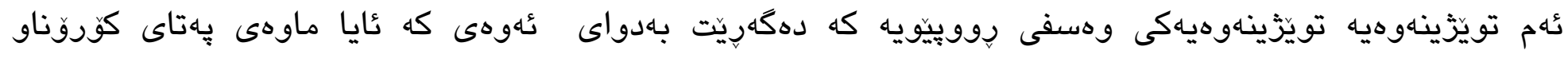
قهدهاهى هاتوجوق و وهستانى زوق له ئيش وكارهكانى دهرهوهى مال، به بئون لاين بوونى زوّربهى كارهكان بوهته هوّى زياتر بهكارهينانى سوّشيال ميديا زياتر له جاران لاى روزّنامهنوسان و رهفتارى بهكارهينانيان،ئايا مـبهست

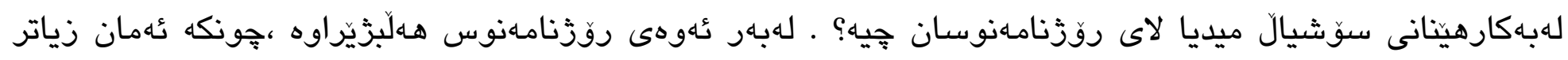

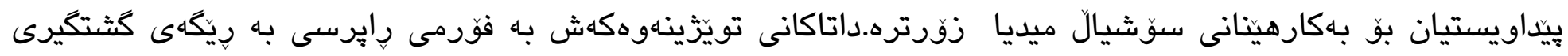

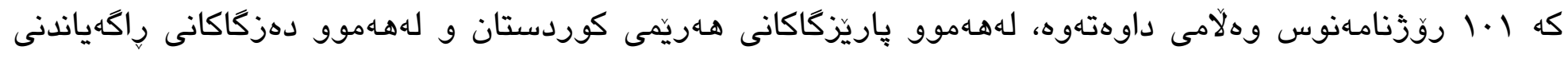
ئون لاين و جاب كراو پِهش. تاكو بكات بهو دهرهنجامهى كه ئايا روزّنامهنوسان سوّشيال ميديا بهكارديّن و

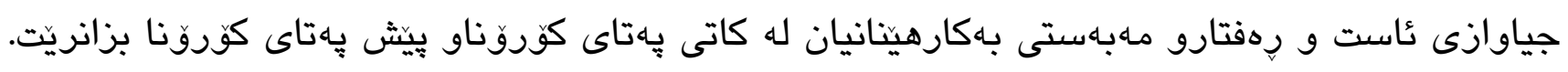

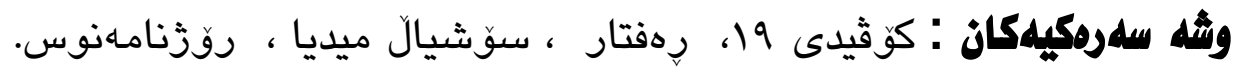




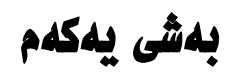

ميتّوَد خامه:

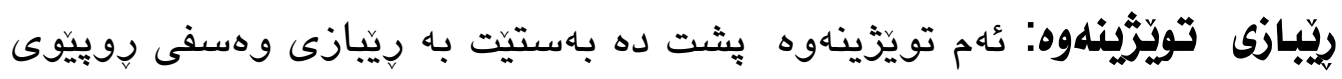
ئامرازهانى تويَزَينهوه :فوَرمى رِايرسى كؤمهلكَهى تويزَينهوهكه: روّزنامهنوسانى هـريّمى كوردستان

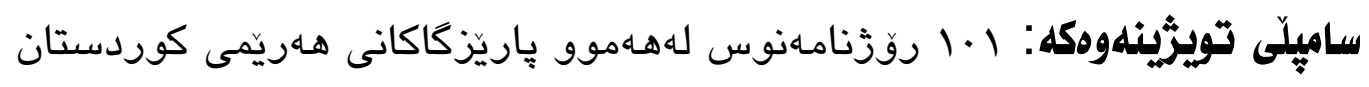

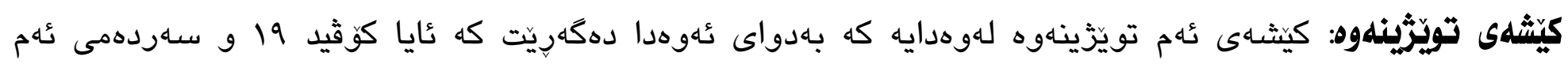
بهايه كه جيهانى بهرهو ئون لاين بردوه ، جوّرهانى سوّيال ميديا كه جيهانى ئون لاينيان قورخ كردوه ،بهكارهينّرهكانيان هيج جياوازيهك له ئاست و رهفتارى بهكارهينانيان دروست بوه له بيّش و دواى هاتنى بهتاى كؤرونا ،زانياريهكان لهسهر كؤثيدى 19 كاريكهرى كردوهته سهر ئاستى بهكارهينانى سوّشيال ميديا ل لاى

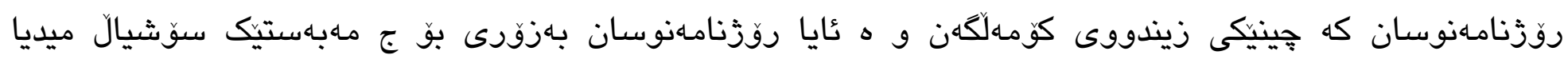
بهكاردينّن

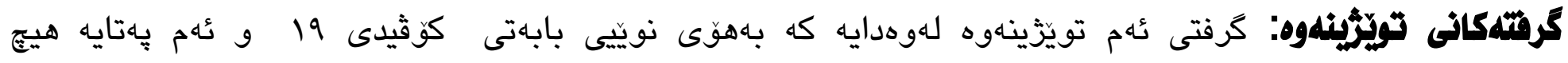

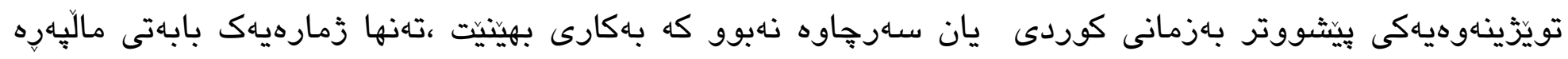

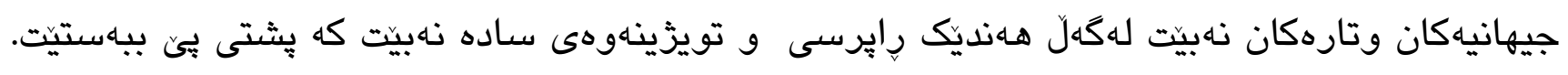




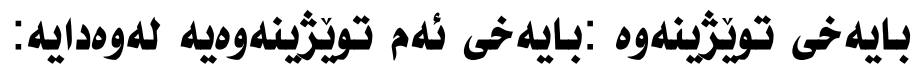

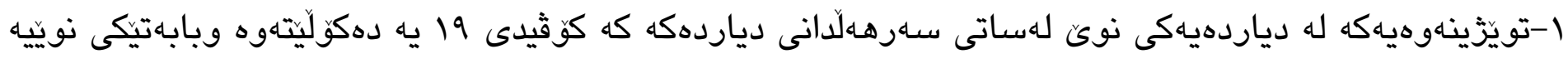
Y-دهبيته بنهمايهك بو تويَّينهوهى زياتر لهم بوراهدا

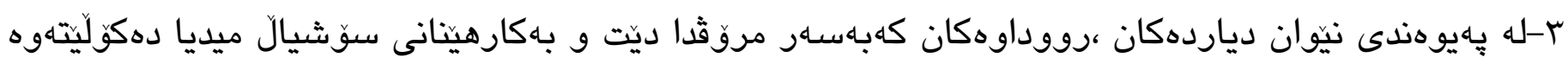
ئامانجى تويَزينهوه:ئهم تويَزَينهوهيه مهبهستيهتى بزانيت:

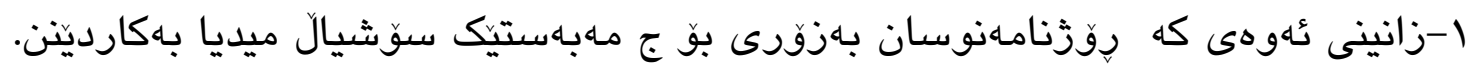

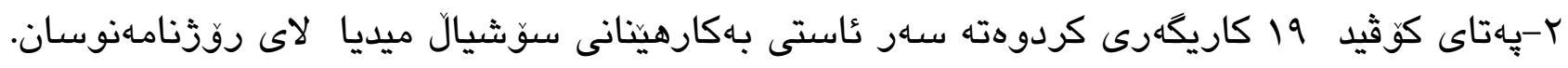

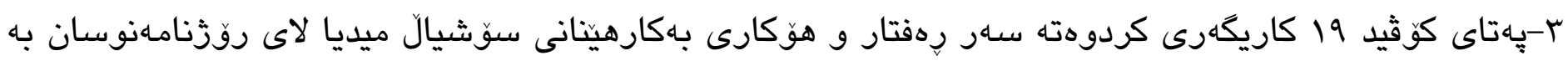

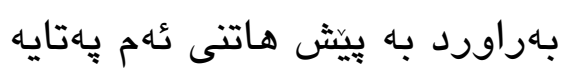

\section{يرسيارهكانى تويَّرينهوه:}

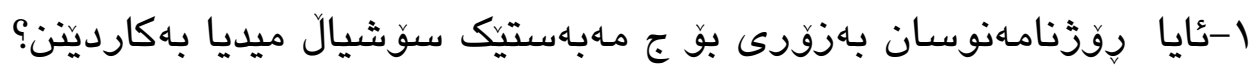

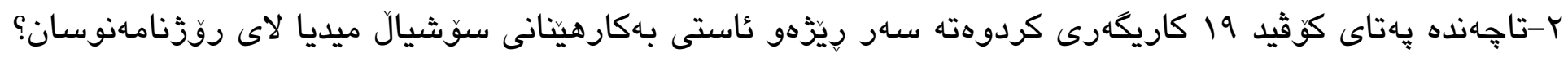

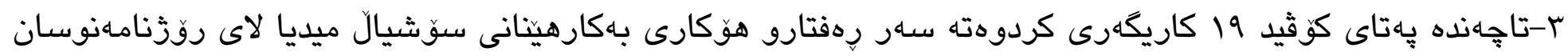

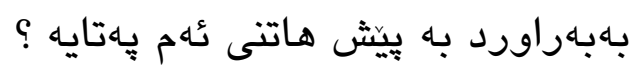




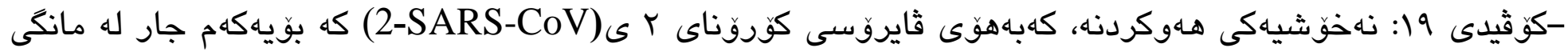

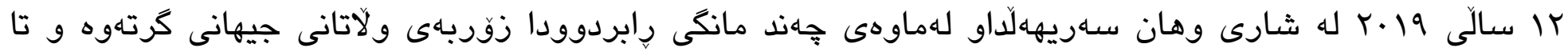

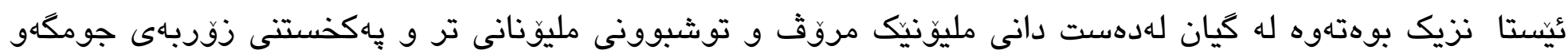

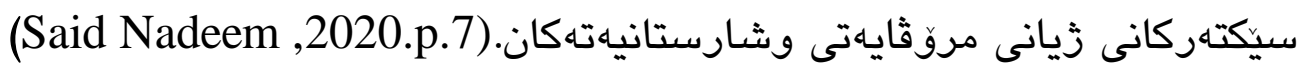

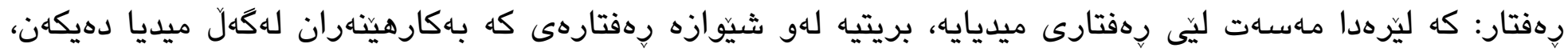

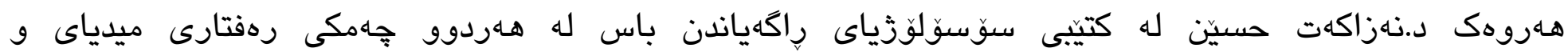

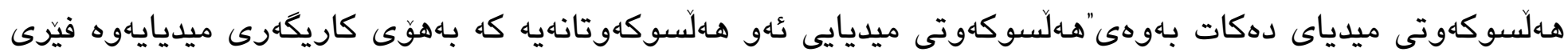

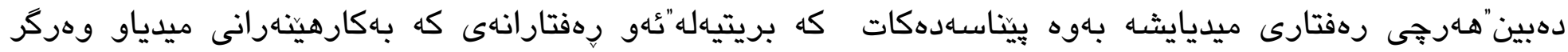

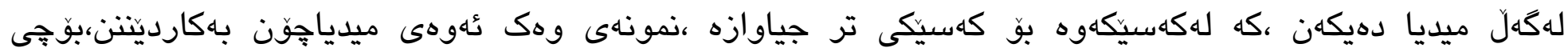

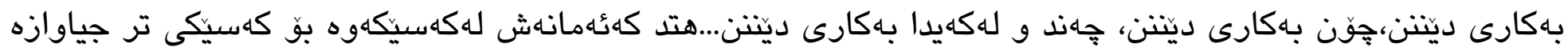

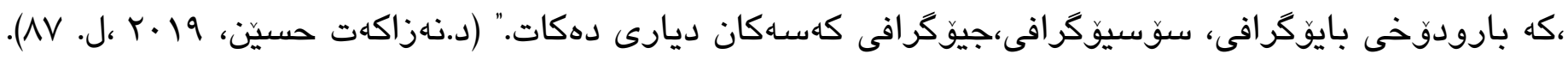

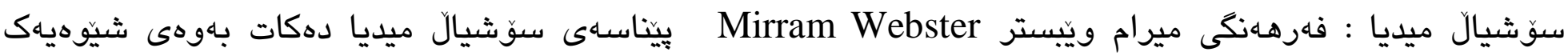

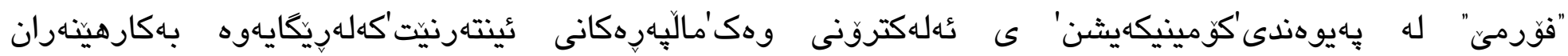

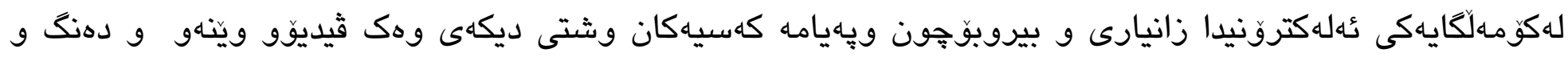

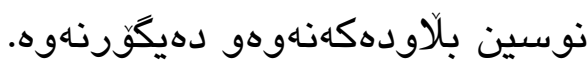

روزنامهنوس :ثٔهو كهسهيه كه زانيارى كودهكاتهوه، دايدريَّزيت و لهيهكيك له دهزكاكانى راكهياندن بلاّوى دهكاتهوه بيَكومان بو دهزكايهكى نوسراو بينراو ياخوود بيستراو دهكّرِيت كارهكانى كه دهنك يان رهنك يان نوسين عامادهكات و بلاّوى دهكاتهوه . (Barbie Zelizer ,2015.p.67)

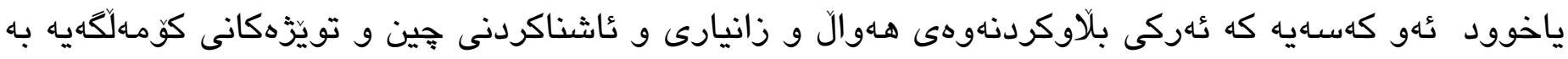

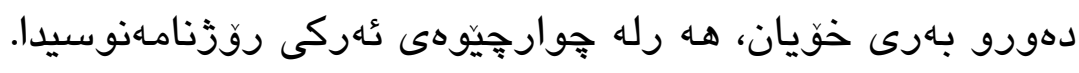




\section{تويَّرينهودكانى يِيَشوو:}

Anneliese D،-Emilie K., Raman P., Annelies W., Heidi L.The pandemic of social media panic travels faster than the COVID-19 outbreak

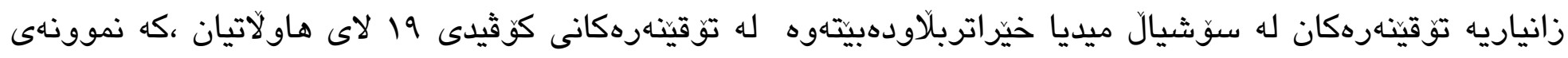

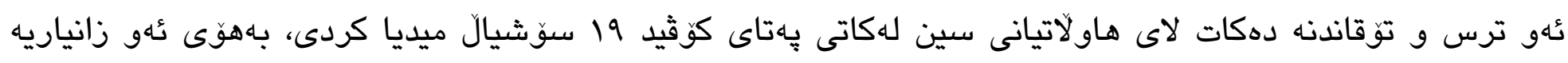
زوّرو ترسينّرانهى بلاوى دهكردهو ه، زوربوونى ريّزّى بهكارهينانى لاى هاولاتيان بو وهركرتنى زانيارى لهسهر

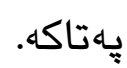

" Coronavirus pandemic and online behavioural shifts تويزينهوهيهى كردوه لهسهر -Alex Gevers-

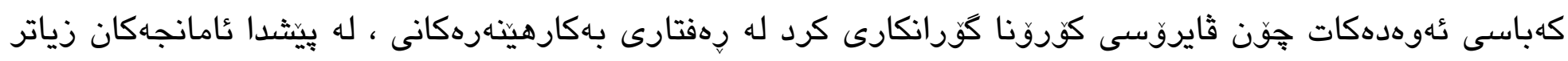

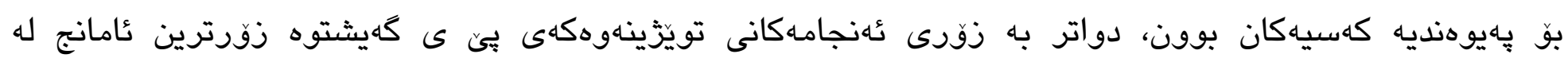

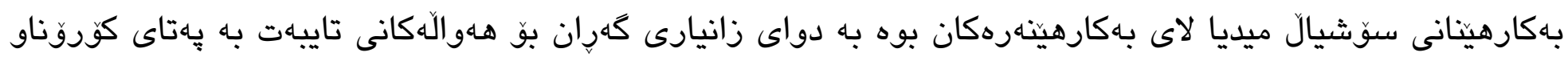
قاهيوهندى به خزم و كهس و كارهكانيان كه لييّان دابِاون، لهبهرامبهردا بهكارهينانى سؤشيال ميديا بو بيّدوايستيهكانى وهك كهشت و برينى بليتى فروكهو دهست خستى ثيزهو... هتد كهم بونهتهوه به ئاستيكى باش بهبهراورد به بيّش كؤرونا.

Consuming media at home due to the 30 - Amy Watson, Marcoronavirus worldwide 2020, by country

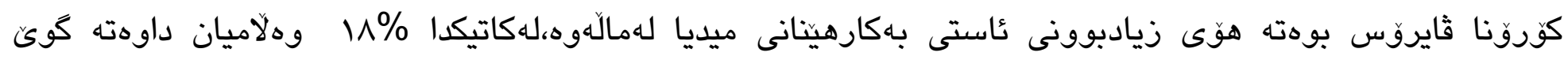

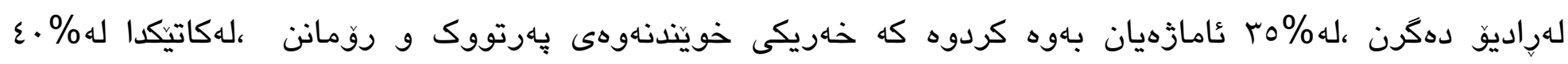
كهبهرزترين ريّزّى وهلامدهرانهوهكان بوو ئامازديان بهوهدابوو كه بهكارهينّهى سوشيال ميديان و كاتهانى خوّيان

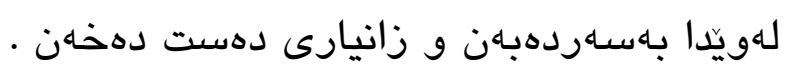


MARKETING AND RESPONSE له مانكى عازارى عُهمسال تويَّزينهوهيهكى كردوه لهسهر James Seligman THE COVID 19 VIRUS "TO دهلّيت كُومانى تيّانيه كه ثايروّى كوّرونا ترازيديايهكى مروّثايهتى بوو ،كاريكهرى كرده سهر ذيانى عابورى و

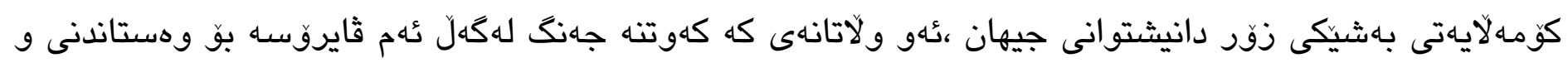

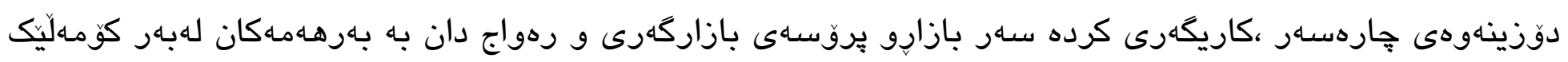

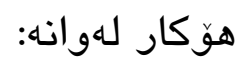

ا-دابِ انى خهلك و مانهوهيان لـمالّكان

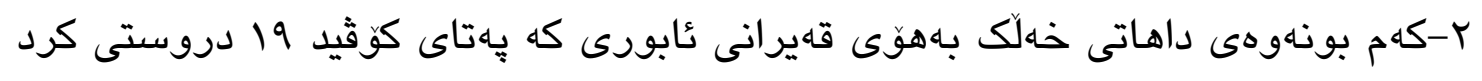

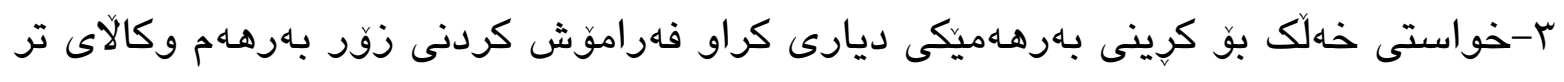
ع- نهكرينى شت و مهك و كهلويهل لهترسى بلاّوبونهوهى ثايروّسهكه 0-كهم بونهوهى جولَهى مروّثهان 7- ترس له مردن 


\section{بالهُى دوومه}

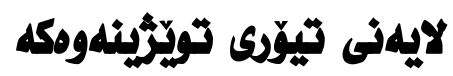

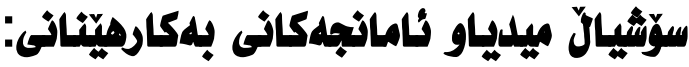

Social Media Marketing"” له كتيبه هاوبهشهكيان N., Vipin K. Dadwal, Sumesh, S. Firdous, A ئامازديان بهوه كردوه كه كهشهى تهكنهلوجيا كارى كردوهته سهر هلموو بوارهانى زيان ، سهرهلآلدانى تهكنهلوجياى

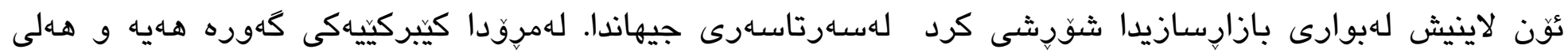
رهخساندوه بو بازارهكان، بهكاربهران كه برياربدهن لهسهر باشترين كالاو خزمهتكوزارى له ريكّهى ئون لاينهوه.

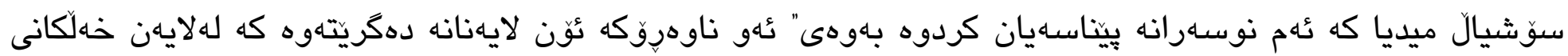

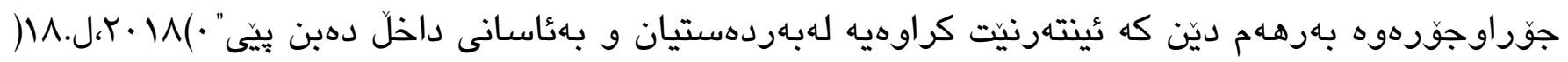

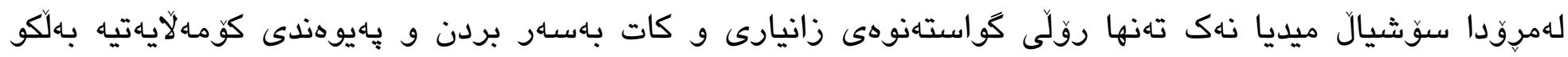

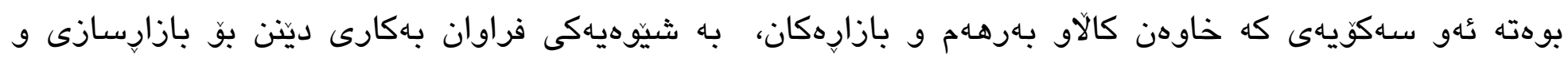

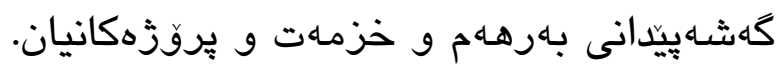

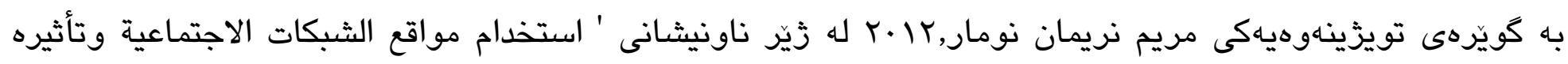

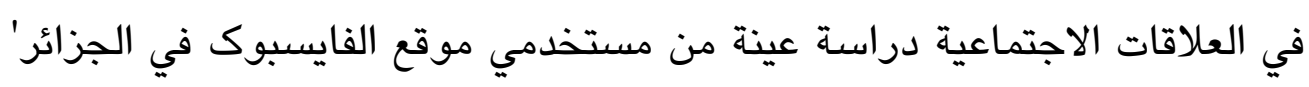

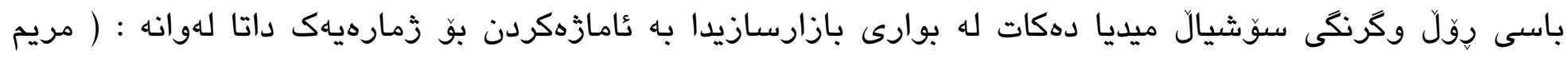

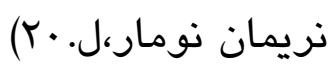

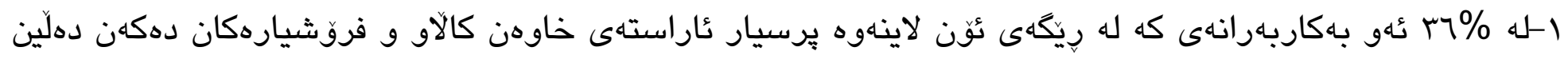

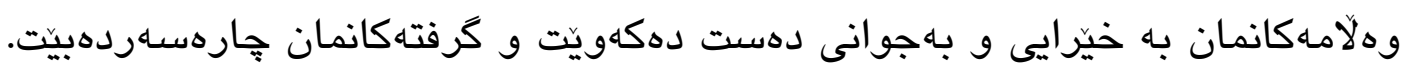

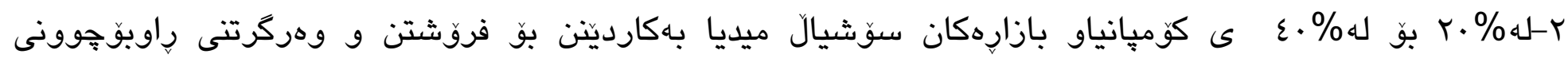
بهكاربهركانيان. 


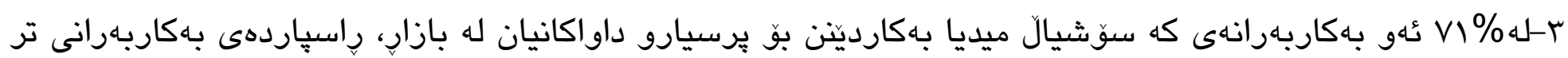

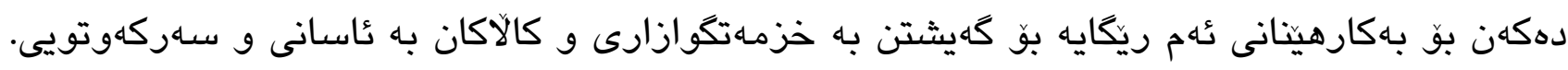

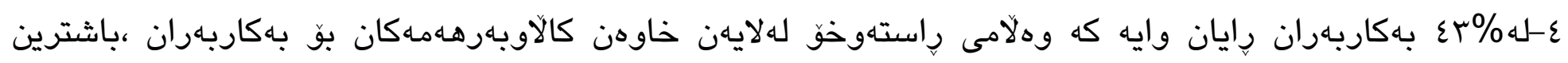

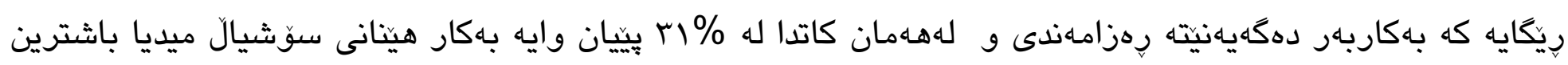

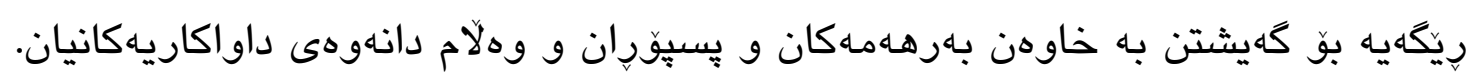

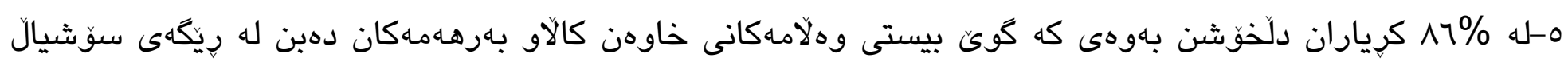
ميدياوه. جكه لهوهى دروست كردنى پِهيوهنديهكى كوماهلايهتى و هاوكارى كردنى بهكاربهر لههـر شوينتيك هـيه . Ahmed, R, I لدوانه:

بلأوكردنهوهى تهكنهلوجيا بو هـموو كهسيك :-Publishing Technology for Everyone

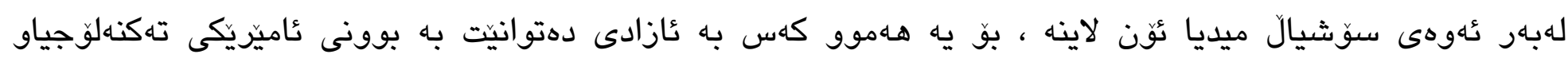

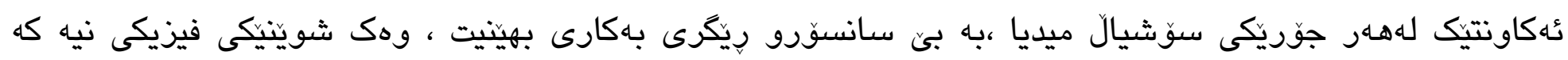

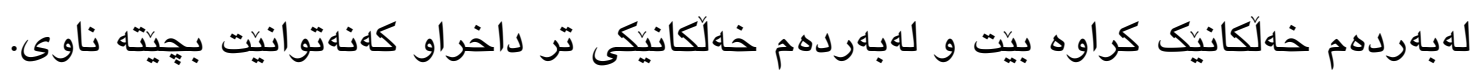

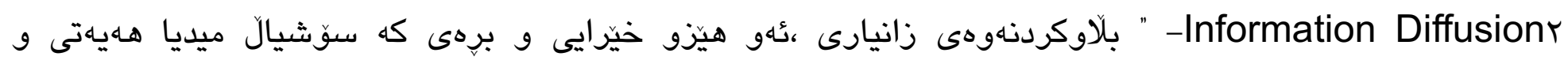

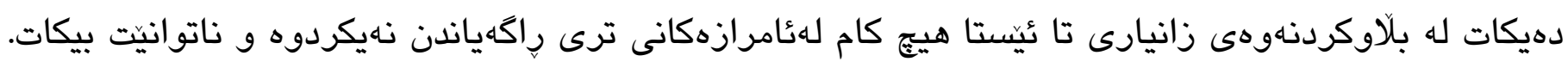

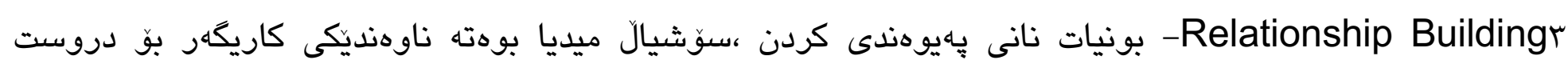

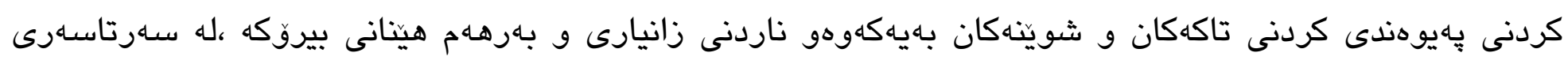

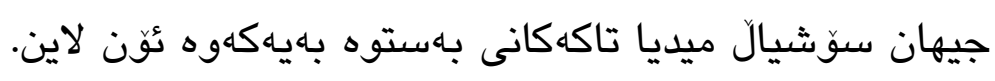




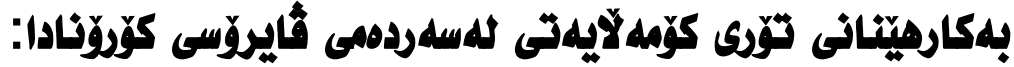

Alex Gevers

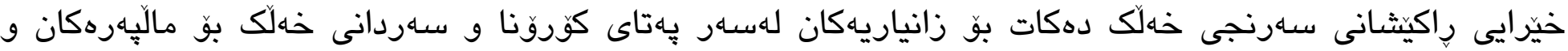

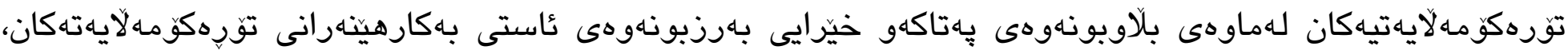

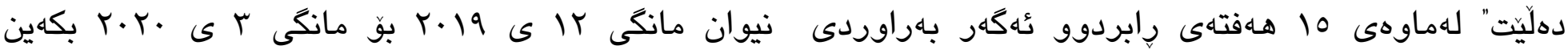

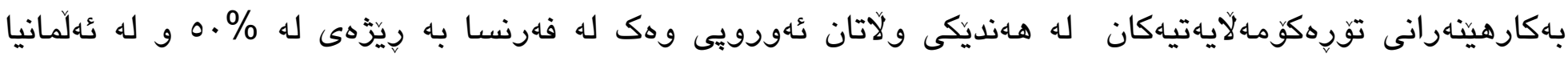

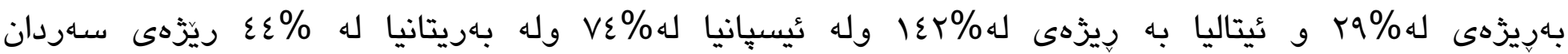
وبهكارهينانى توردكومهلايهتيهكان بهرزبوهتهوه ،بههوى كهران و زانينيان بو هلوالّكان تايبه به ثايروسى كورنا."

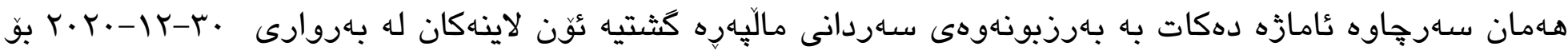

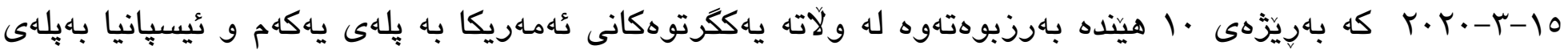

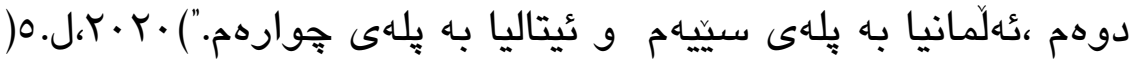

به كُويرهى دهرهنجامى دوو تويَّينهوه كه ناوهنى IZEA Worldwide كردويهتى باوهريان وايه كه بهكارهينهرانى

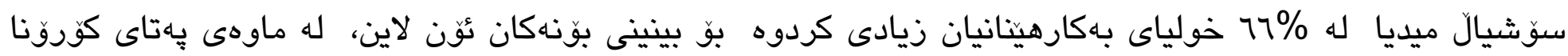

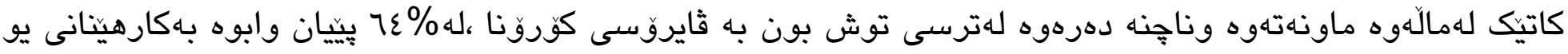
تيوب زياد بوه لايان، تهنها له\%ب بيّيان وايه كهمى كردوهله \%ب بيّيان وابوه كه بهكارهينانى فهيسبوكيان زيادى

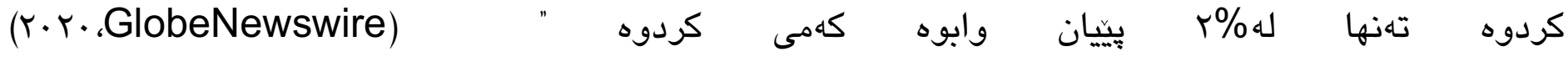
How Coronaviruses Will Change User's 2020, Joele Fforrester Social Media Habits

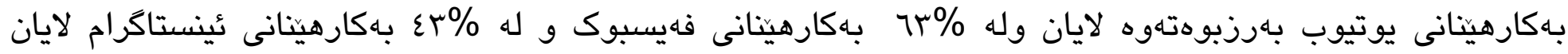


بهارزبوهتهوه ,لهبارهى كرينى شت ئون لاين له 99\% يان بيّيان وابوه كه بههوى عُوهى لهمالّوهن خوليايان بو كرينى

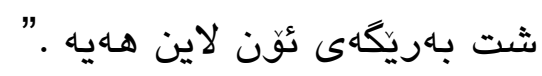

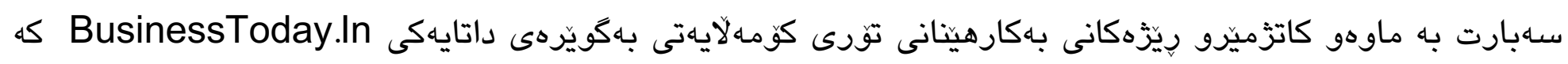
رايرسيهكى لهنيوان هاولآتيانى هيندستان كردوه ،دهرهكهوتوه يِيش كهرهنتينهو جونهوه مال بهرزترين ريّزَهى كاتى

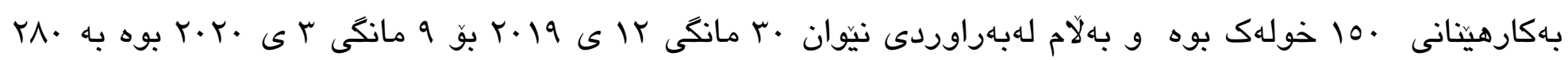

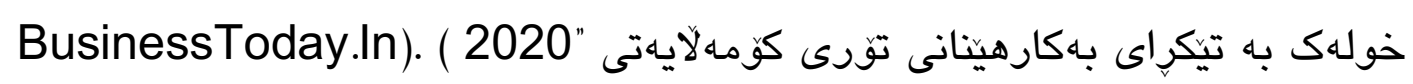

له بارهى ئهوجورانهى بهكارهينان كه كهمى كردوه Alex Gevers له رإيرسيهكهيدا كهشتوه بهوهى كه بهكارهينانى تورى كومهالايهتى بو مهبهستى بيّداويستيهكانى كَهت كردن هـر لهدهتخستنى ثيزهو برِينى بليتى فروكهو كرنتى

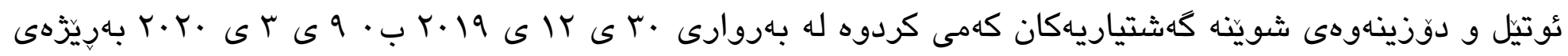

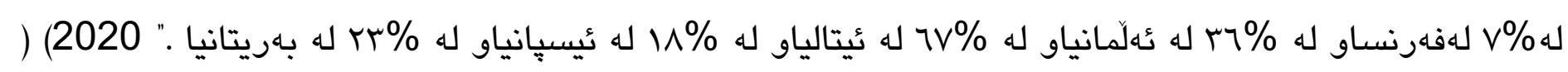

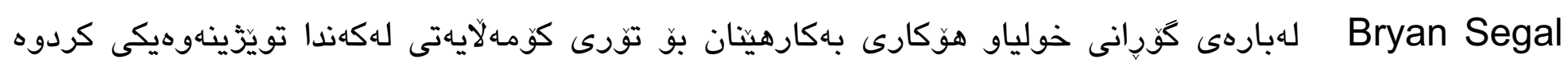
لهسبر

"Coronavirus Crisis is Dramatically Impacting Digital Media Consumption in Canada بهماناى 'ثايروّسى كوّرونا بهشيّوهيهكى دراماتيكى كاريكهرى كرده سهر بهكارهينانى ميدياى ديجيتالّى له كهنها' كه

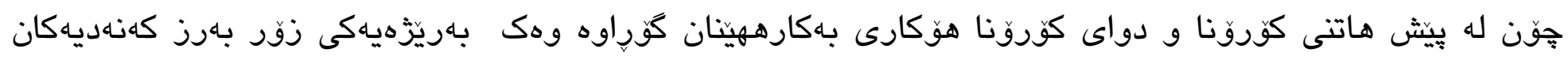

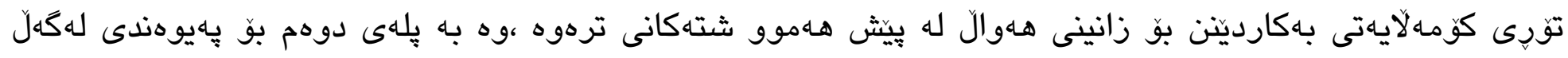

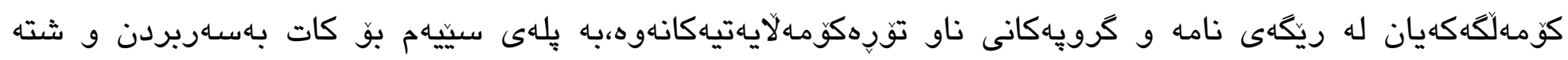

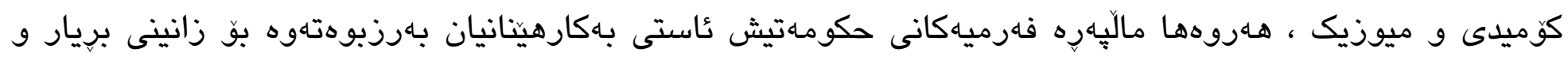

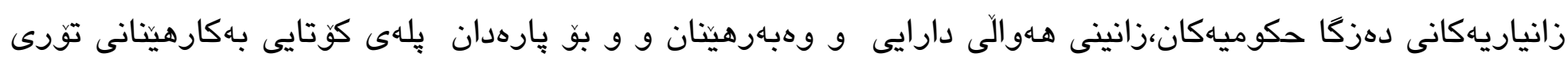
كوّماهلايهتى بوه."

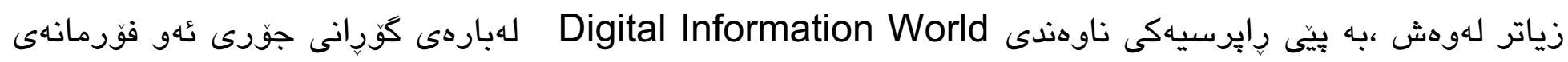

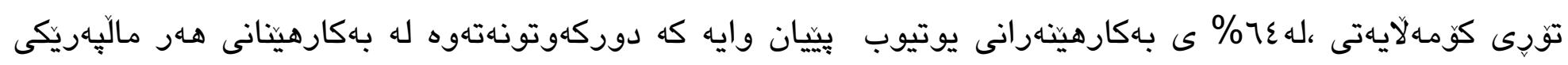




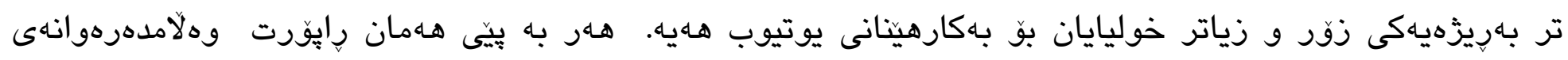

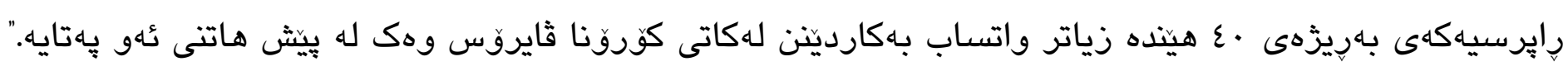

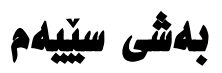

\section{لايهنى مهيدانى تويّلَينهومكه}

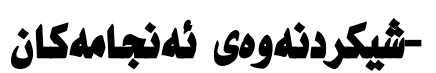

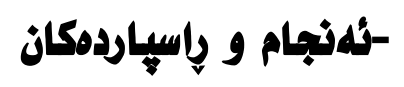

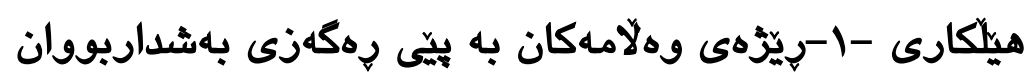

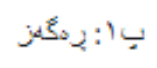

101 responses
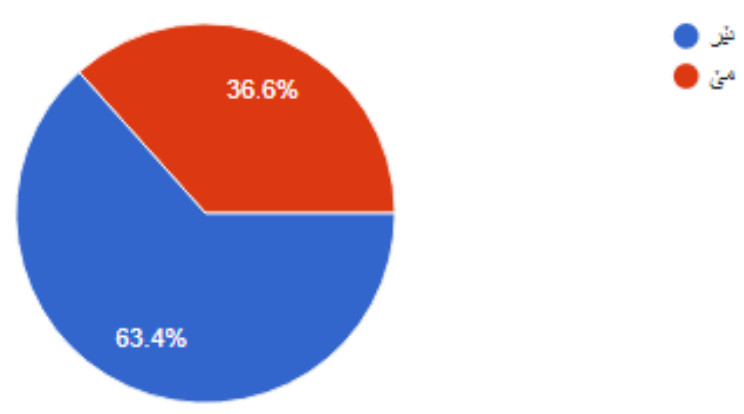

خشتهى زماره ا تايبهت به رهكهزى بهرتويزّهكان

\begin{tabular}{|c|c|c|}
\hline ريّزْهى سهدى & دووباردبونهوه & \\
\hline \% \% & rv & نيّز \\
\hline \%rา,7 & $7 \varepsilon$ & 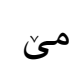 \\
\hline$\% 1 .$. & 1.1 & كو \\
\hline
\end{tabular}




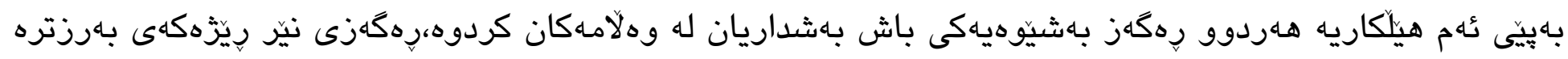

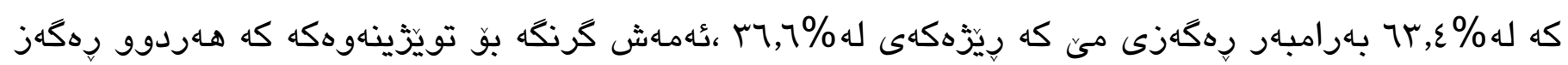

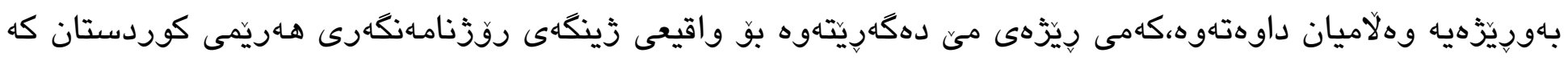

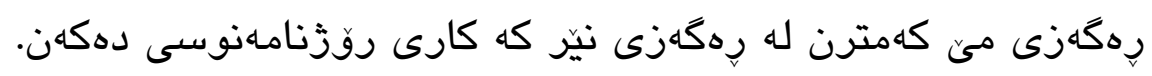

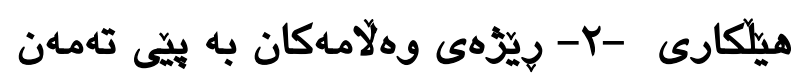

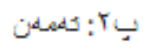

101 responses
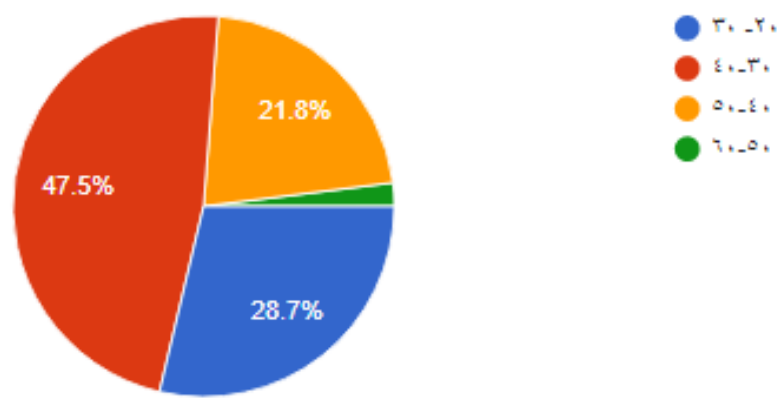

T...

خشتهى زُماره Y تايبهت به تهمهنى بهرتويّزهكان

\begin{tabular}{|c|c|c|}
\hline ريّزهى سـهدى & دووبارهبونهوه & تُاستهكانى تهمـن \\
\hline \% Y^,V & $r q$ & $r \cdot-r$. \\
\hline$\% \varepsilon \vee, 0$ & $\varepsilon \wedge$ & $\varepsilon \cdot-r$. \\
\hline \%r।,A & rt & $0 \cdot-\varepsilon$. \\
\hline \%r & r & $7 \cdot-0$. \\
\hline$\% 1 \ldots$ & $1 \cdot 1$ & كو \\
\hline
\end{tabular}

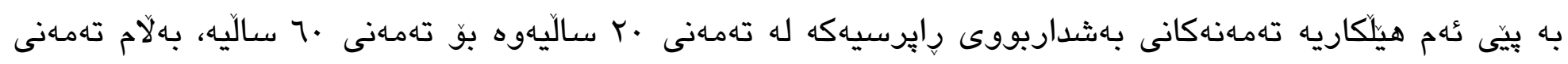

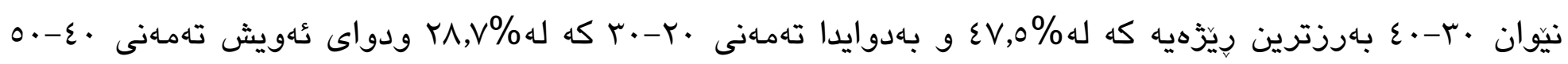




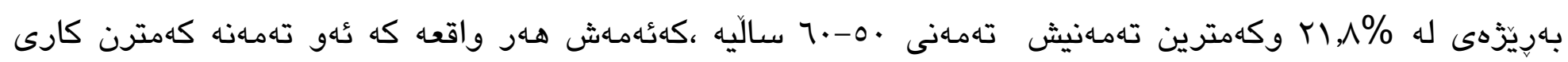

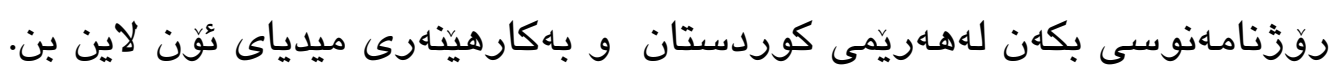

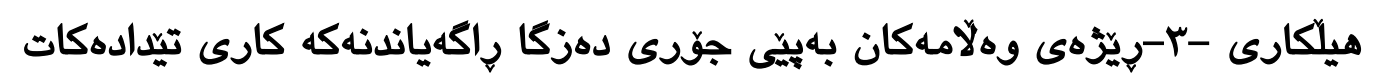

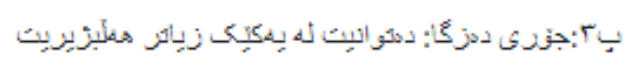

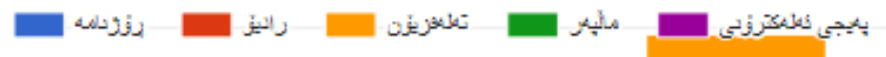

40

20

0
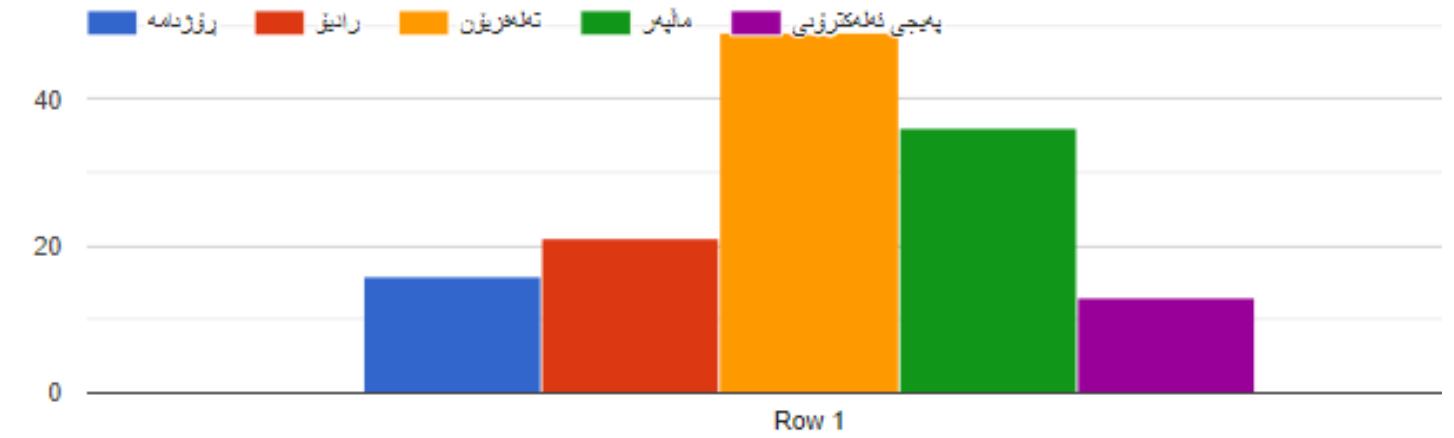

خشتهى زماره ب تايبهت به شوينكارى بهرتويّزّكان

\begin{tabular}{|c|c|c|}
\hline ريّزَهى سهادى & | دووبارهبونهوه & جورىى دهزكاى راكهياندن \\
\hline \%rา,r & $\varepsilon q$ & تهله فيزيوّن \\
\hline$\% \backslash 0,7$ & rI & راديوّ \\
\hline$\% 11,9$ & 17 & روَزَنامـه \\
\hline$\% 9, \mathrm{~V}$ & $\pi$ & سايتى كُهلكتروّنى \\
\hline$\%$ \%r, & $r 7$ & مالِّهرى كومهالآياتى \\
\hline$\% 1 \ldots$ & ro & كو \\
\hline
\end{tabular}

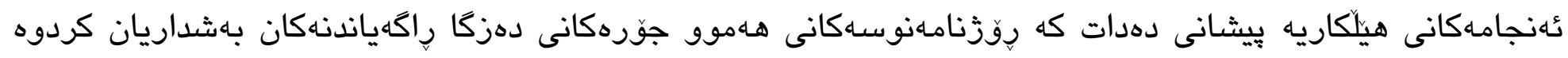

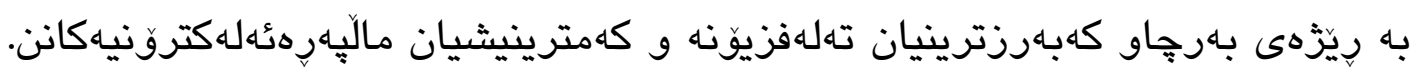


هيلكارى -ع- ريّرّهى وهلامهكان به بيّى ناستى خويتدهوارى

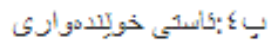

101 responses
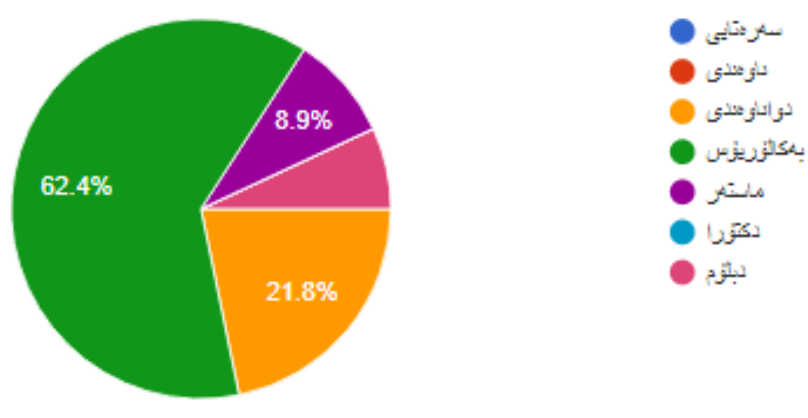

خشتهى زُماره ع تايبهت به ئاستى خويندهوارى بهرتويّزهكان

\begin{tabular}{|c|c|c|}
\hline ريزّهى سـهدى & دووبارهبونهوه & ئاستى خويندهوارى \\
\hline$\%$ & $\cdot$ & سـردتايى \\
\hline$\%$. & . & ناوهندى \\
\hline$\%$ \%r, & KT & دواناوهندى \\
\hline 7,9 & V & دبلوم \\
\hline \%тr,乏 & $7 \pi$ & بهكالوريوّس \\
\hline$\Lambda, 9$ & 9 & ماستهر \\
\hline$\%$. & . & دكتورا \\
\hline$\% 1 \ldots$ & 1.1 & كو \\
\hline
\end{tabular}




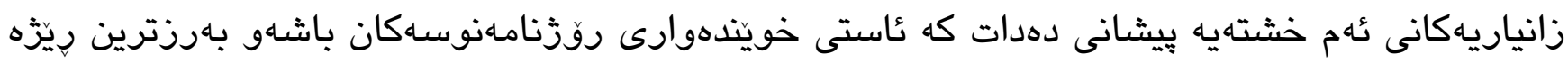

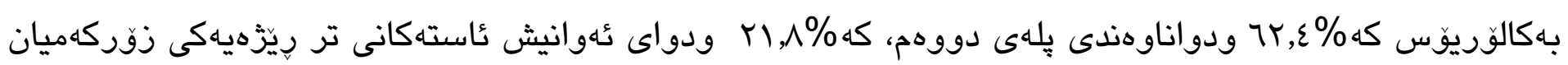
هـهيه .

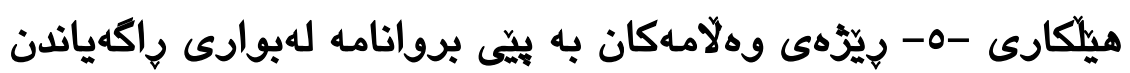

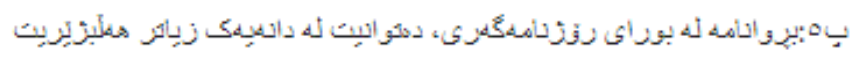

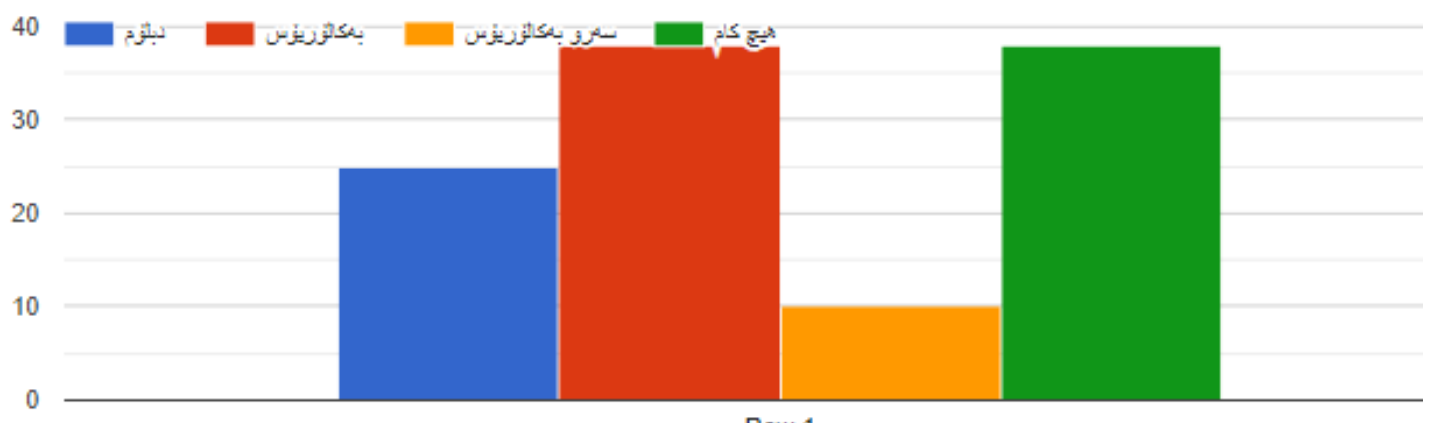

خشتهى زماره ه تايبهت به بروانامهى بوارى روزّنامهكهرى

بهرتويزّهوكان

\begin{tabular}{|c|c|c|}
\hline ريّزهى سـهدى & دووبارهبونهوه & بروانامهى بوارى روخزنامـكَهرى \\
\hline \%rع,r & r^ & هيج كام \\
\hline$\% 9$ & 1 . & سـهرو بـكالؤريوّس \\
\hline$\% r \varepsilon, r$ & r人 & به بـالوريوّس \\
\hline \%rr, & ro & دبلوَم \\
\hline$\% 1 \ldots$ & 111 & كو \\
\hline
\end{tabular}




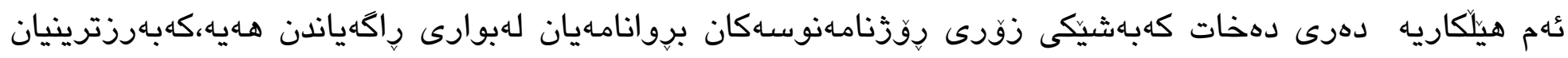

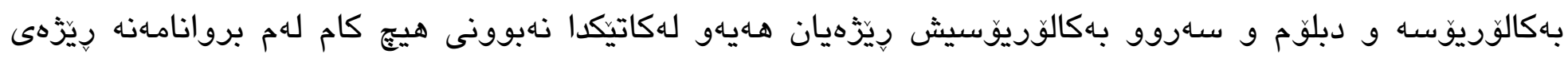

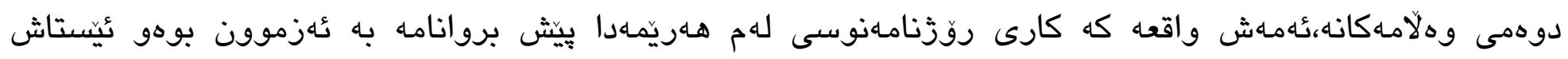

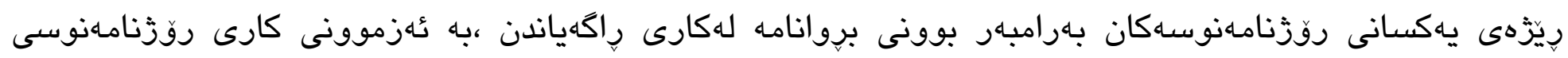

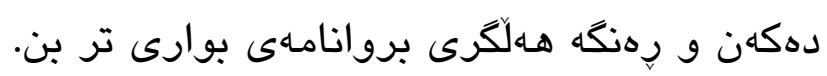

هيلكارى -7- ريّزّهى وهلامهكان به بيّى بهشدارى خولى رِاكهياندن

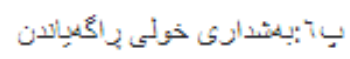

101 responses
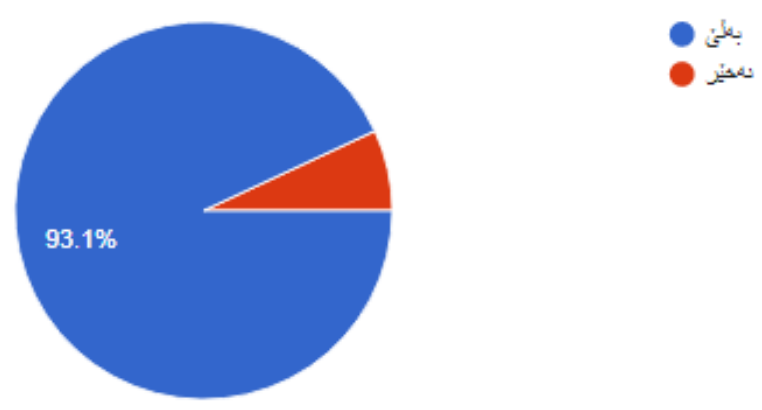

خشتهى زماره 7 تايبهت بهشدارى له خولى راكهياندنى

بهرتويَّركان

\begin{tabular}{|c|c|c|}
\hline ريّزَهى سـدى & دووبارهبونهوه & بهشدارى له خولى راكهياندن \\
\hline$\% 94,1$ & $9 \varepsilon$ & بهلّئ \\
\hline$\% 7,9$ & $\mathrm{~V}$ & نهخيَر \\
\hline$\% 1 \ldots$ & 1.1 & كو \\
\hline
\end{tabular}




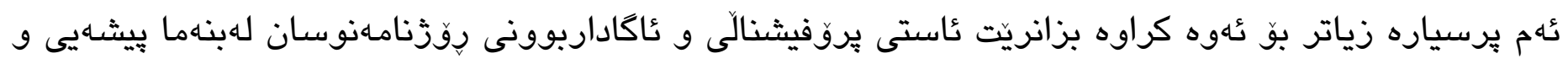

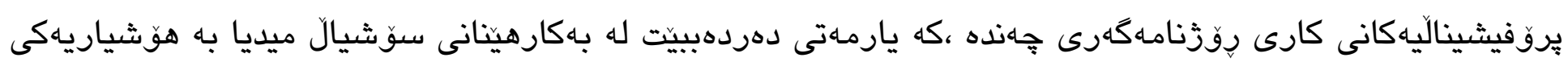
ميديايهوه . ترويا.

\section{هيَّكارى -V- ريّزّهى وهلامهكان به بيّى جوردى كارهكهى لهناو دهزكا}

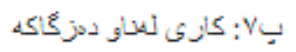

101 responses

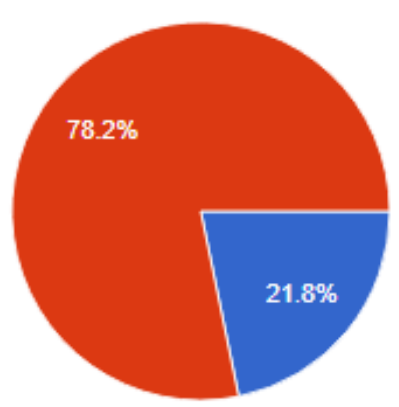

خشتهى زماره V تاييهت به جوّرى كار له نيّو دهزكاى راكهياندن بهرتويّزّكان

\begin{tabular}{|c|c|c|}
\hline ريزّهى سـادى & دووبارهبونهوه & جوّرى كار له نيّو دهزكاى راكهياندن \\
\hline$\% \vee \wedge, Y$ & v9 & روّزنامهنوس \\
\hline$\%$ \%r, & rT & بهاريّوهبهر \\
\hline$\% 1 .$. & 1.1 & كو كو \\
\hline
\end{tabular}

زانياريهكانى ئهم هيلّكاريه جوّرى كارى روزّنامهنوسهكه لهناو دهزكاكهدا بيشان دهدات تاكو بزانريت هـموويان كارى

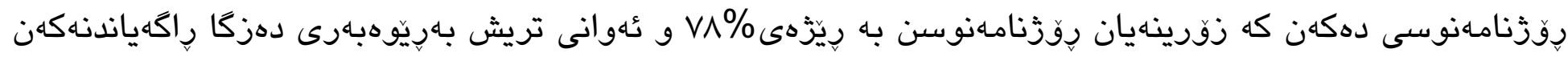

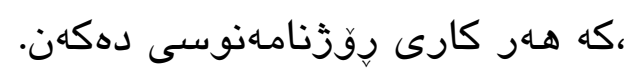




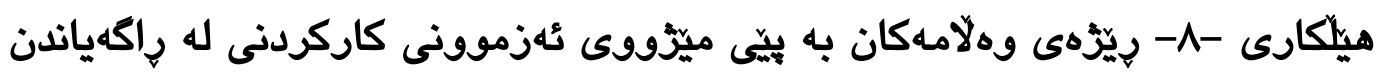

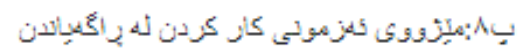

101 responses
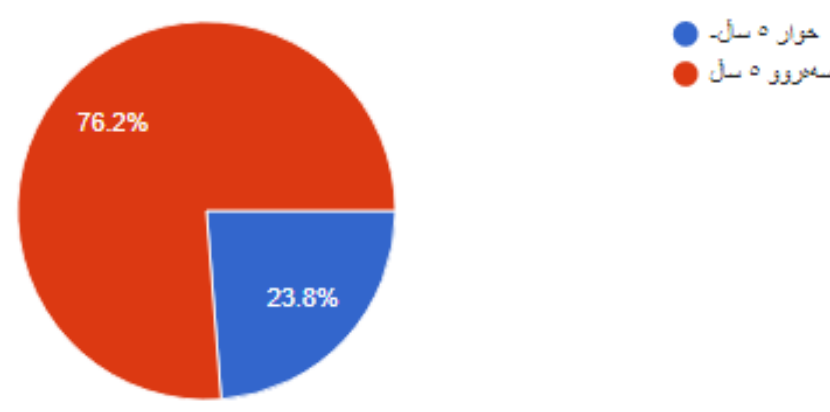

C

خشتهى زُماره ^ تايبهت به تُهموونى كاركردنى بهرتويّزهكان

\begin{tabular}{|c|c|c|}
\hline ريّزَهى سهادى & دووبارهبونهوه & ئهزموّنى كاركردن \\
\hline \% \%r,^ & $r \varepsilon$ & كهمتر له بِينج سال \\
\hline$\% \vee 7, Y$ & VV & زياتر له يِينج سال \\
\hline$\% 1 .$. & 1.1 & كو \\
\hline
\end{tabular}

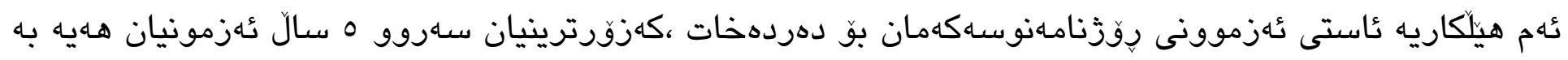

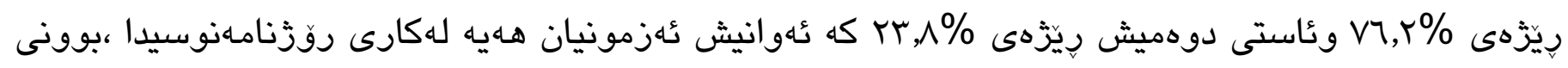

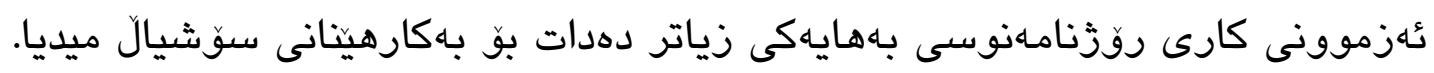




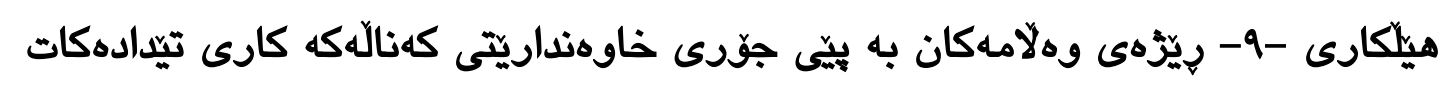

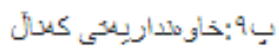

101 responses
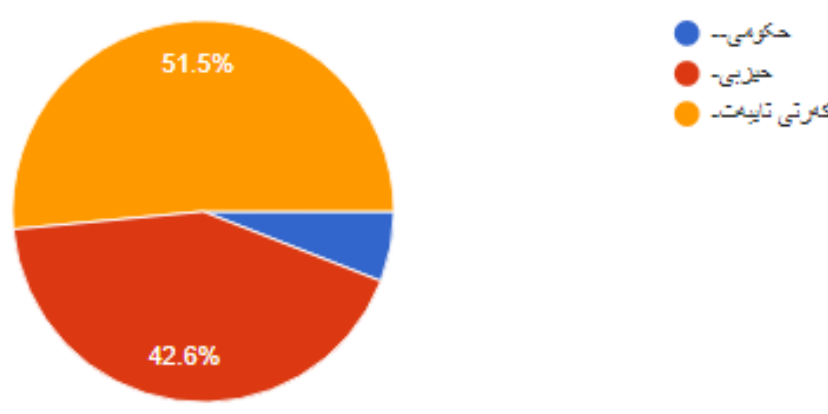

خشتهى زُماره 9 تايبهت به خاوهنداريّتى كهنالَى بهرتويّزهكان

\begin{tabular}{|c|c|c|}
\hline ريّزَهى سـادىى & دووبارهبونهوه & خاوهنداريّتى كهنال \\
\hline$\% 0,9$ & 7 & حكومى \\
\hline$\% \varepsilon r\rceil$, & or & حيزبى \\
\hline$\% 01,0$ & $\varepsilon r$ & كهرتى تايبهت \\
\hline$\% 1 \ldots$ & $1 \cdot 1$ & كق \\
\hline
\end{tabular}

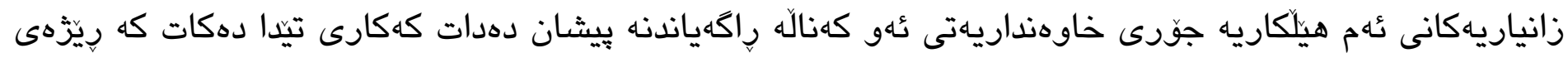

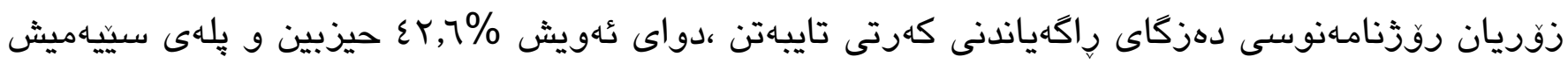

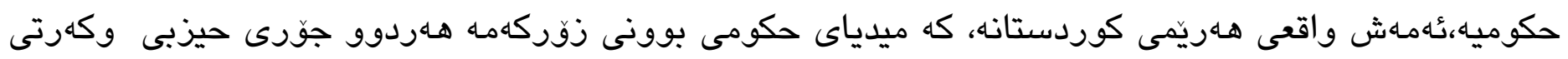
تايبهت قورخى زينكه ميديايهكهيان كردوه . 

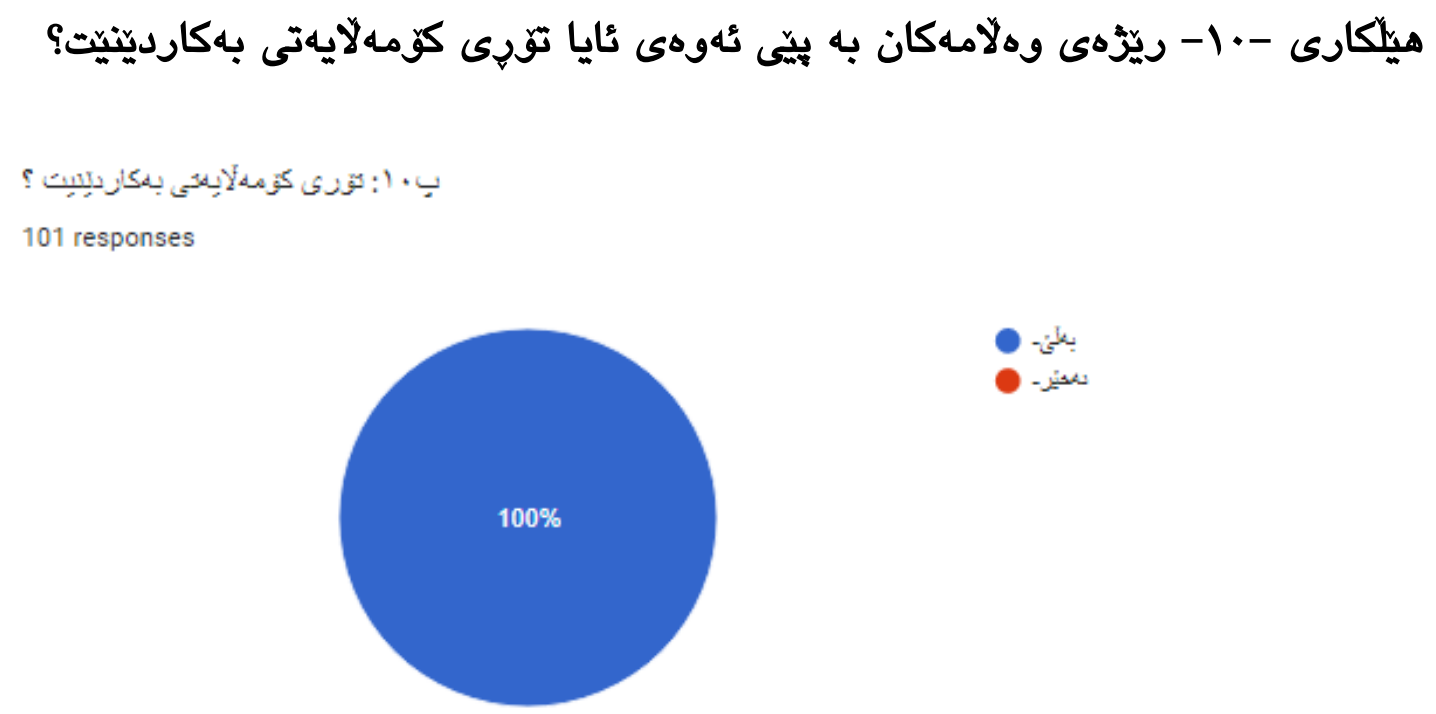

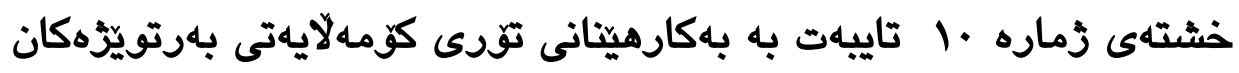

\begin{tabular}{|c|c|c|}
\hline ريزّنهى سهادى & لدوبارهبونهوه & بـكارهينانى تورىى كومـهلاِيـهتى \\
\hline$\% 1 \cdots$ & $1 \cdot 1$ & بـهلَّن \\
\hline$\%$ & $\cdot$ & نهاخيّر \\
\hline$\% 1 \cdots$ & $1 \cdot 1$ & كو \\
\hline
\end{tabular}

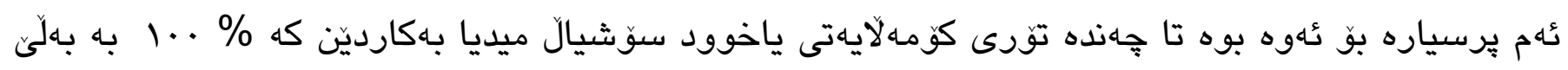
رِيَّهـ 


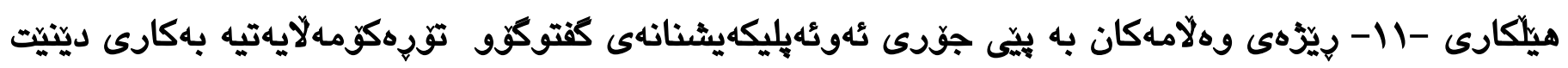

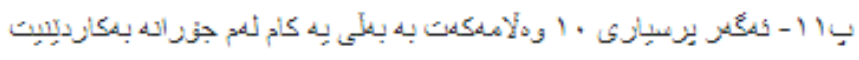

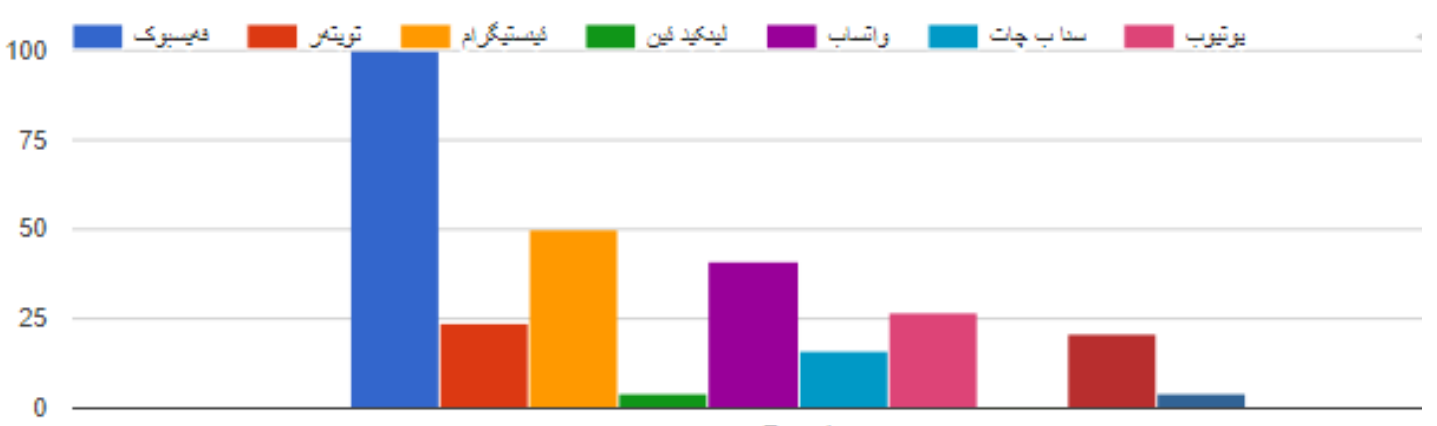

Row 1

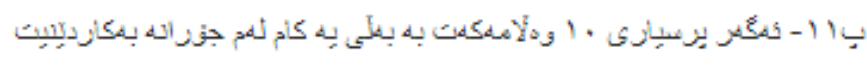

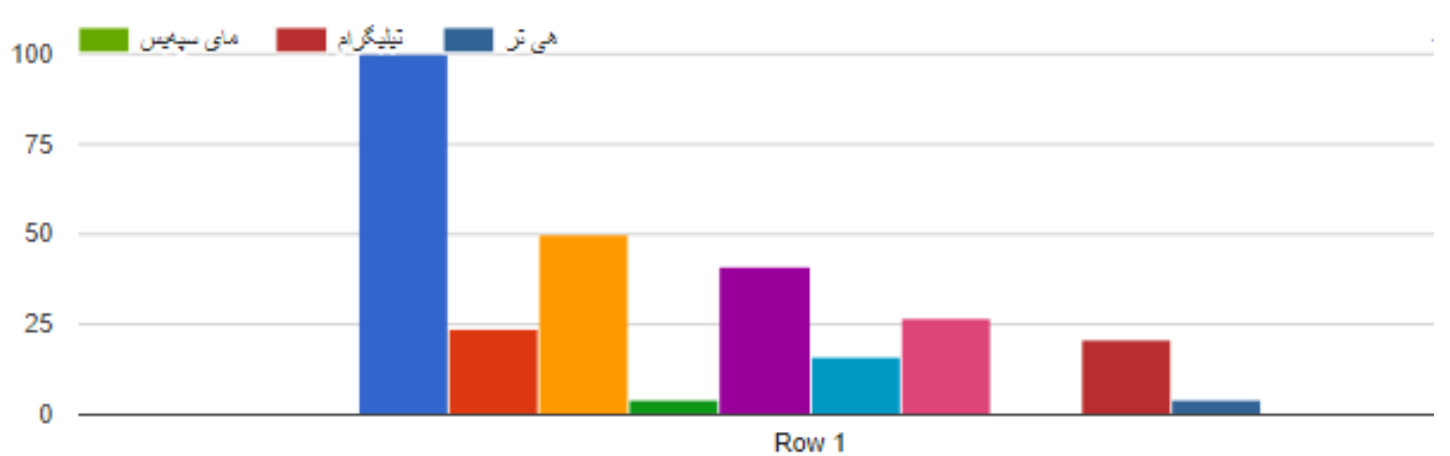




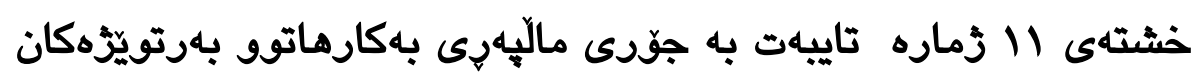

\begin{tabular}{|c|c|c|}
\hline ريّزدى ساهدى & دووبارهبونهوه & جوّرى مالَّهر \\
\hline$\% 9, \varepsilon$ & TV & يوتيوّب \\
\hline$\% 0,7$ & 17 & سناب جֶات \\
\hline$\% \backslash \varepsilon, r$ & ह1 & واتسئاب \\
\hline$\% 1, \varepsilon$ & $\varepsilon$ & لينكيدن \\
\hline$\% \backslash \vee, \varepsilon$ & 0. & ئينستكرام \\
\hline$\% \wedge, \varepsilon$ & $r \varepsilon$ & تويتهر \\
\hline$\% r \varepsilon, \wedge$ & $1 \cdots$ & فهيسبووك \\
\hline$\%$. & $\cdot$ & مايسيهيس \\
\hline$\% \vee, r$ & rI & تيليكرام \\
\hline$\% 1, \varepsilon$ & $\varepsilon$ & هيتر \\
\hline$\% 1 \ldots$ & TAV & كو \\
\hline
\end{tabular}

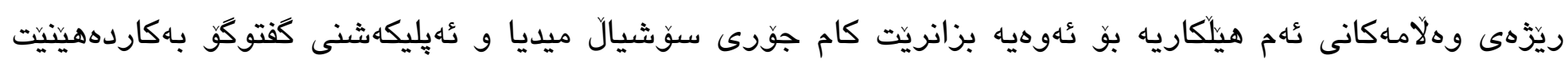

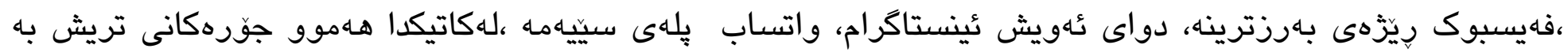

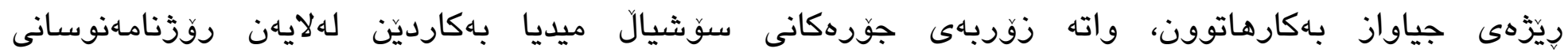

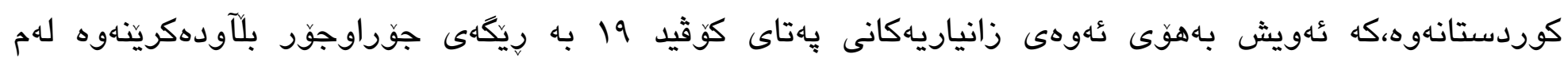
ماوهيهدا. 


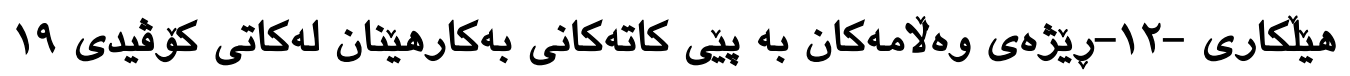

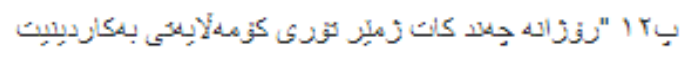

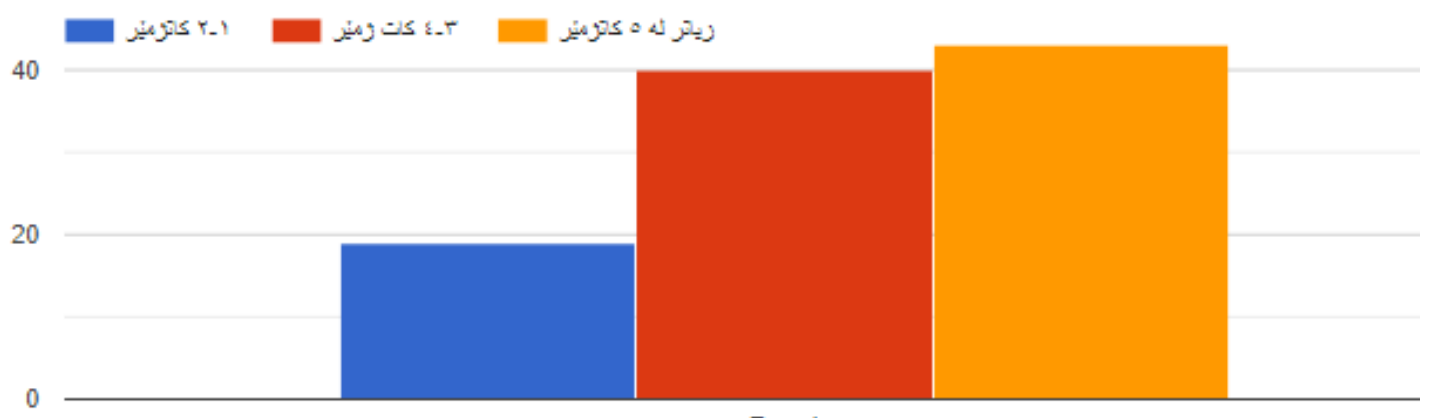

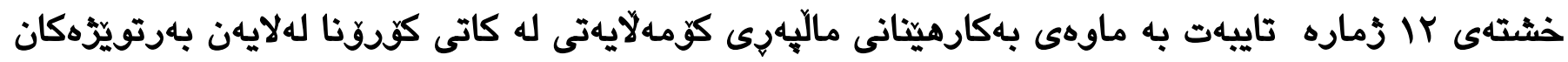

\begin{tabular}{|c|c|c|}
\hline ريّزهى سـدى & دووبارهبونهوه & 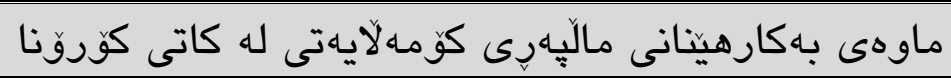 \\
\hline$\% \backslash \wedge, \wedge$ & 19 & 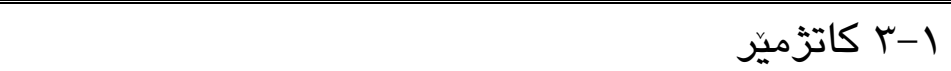 \\
\hline$\%+q, 7$ & $\varepsilon$. & 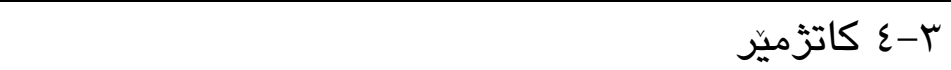 \\
\hline$\% \varepsilon 1,7$ & $\varepsilon r$ & زياتر له يِيتج كاتزّميّر \\
\hline$\% 1 .$. & 1.1 & كو \\
\hline
\end{tabular}

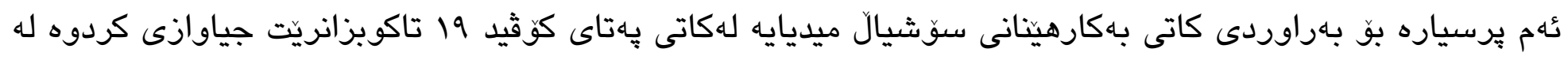

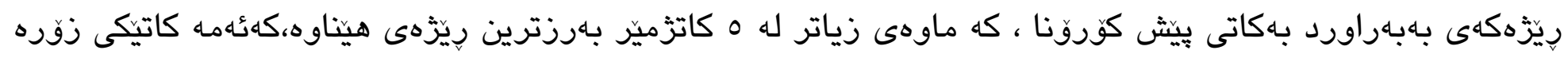

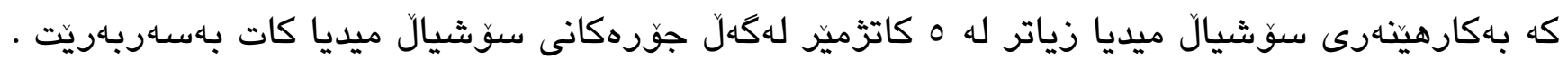




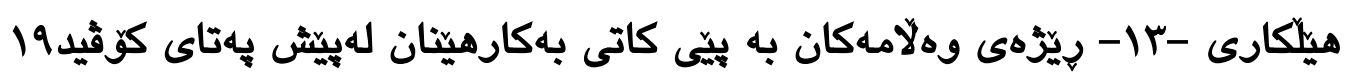

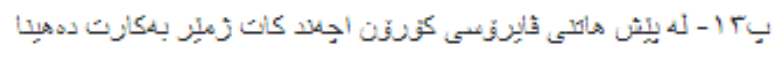

99 responses

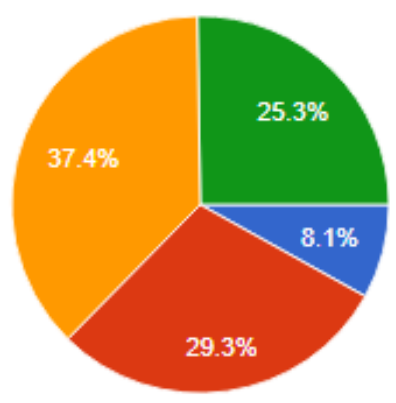

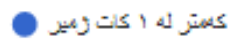

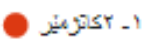

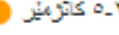

ريقر لـ مكتومئز

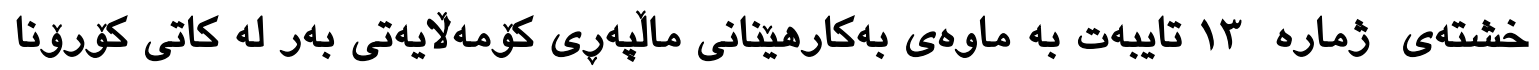

\begin{tabular}{|c|c|c|}
\hline ريّزلهى سـادى & دووبارهبونهوه & 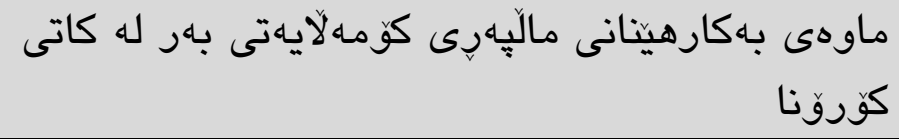 \\
\hline$\% \wedge, 1$ & $\wedge$ & كهمتر له ا كاتزميّر \\
\hline$\%$ \% r r & $r q$ & ا Y- كاتزّميّر \\
\hline$\% r v, \varepsilon$ & rV & r-ه كاتزَميّر \\
\hline \%ro,r & TV & زياتر له ه كاتزميّر \\
\hline$\% 1 .$. & 1.1 & كو \\
\hline
\end{tabular}

زانياريهكانى ئهم هيلكاريه جياواز له هيلّكاريهكهى يِيشوو كاتهكانى بهكارهينانى سوّشيالَ ميديا لاعى روزّنامهنوسان

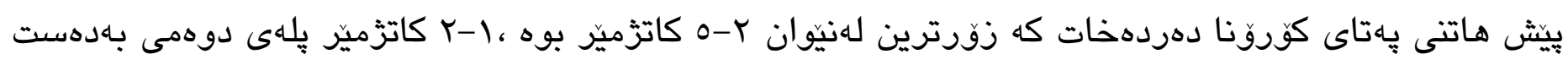

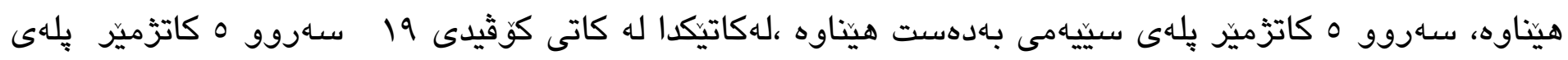

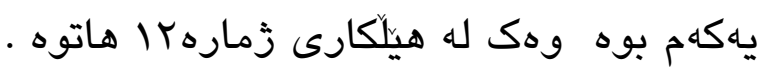




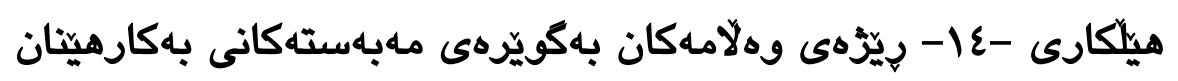
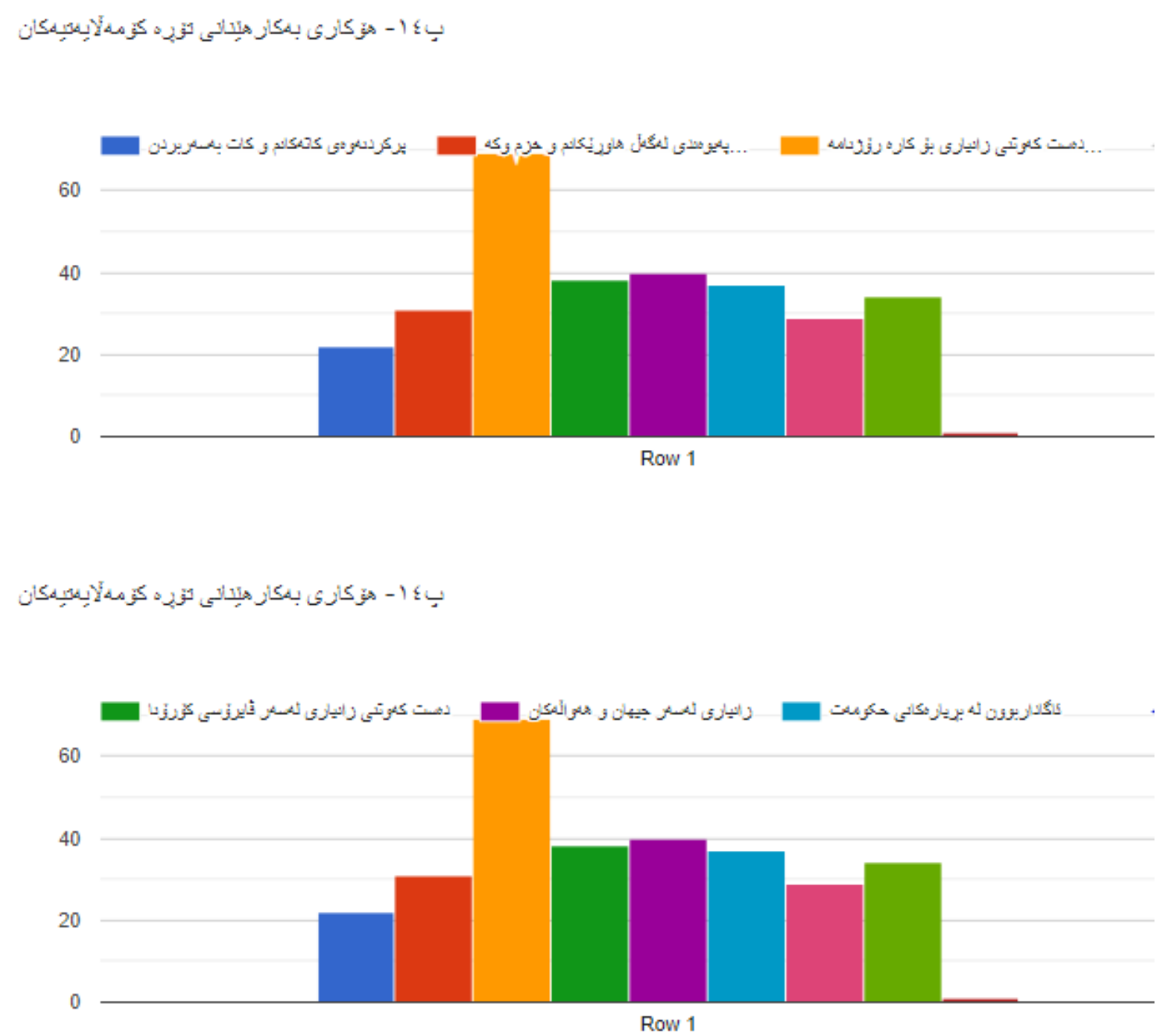

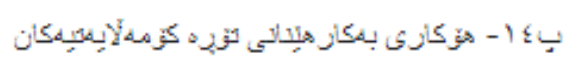

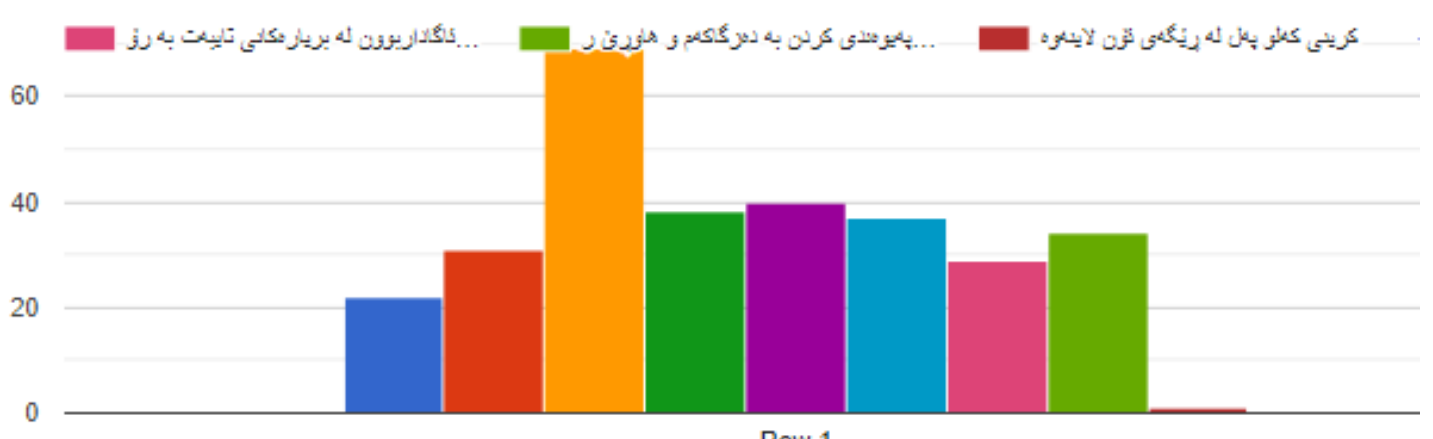




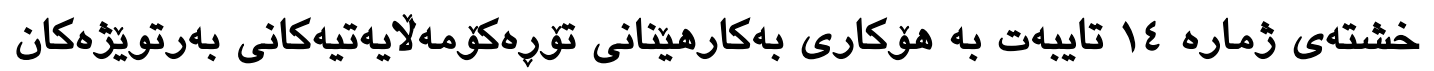

\begin{tabular}{|c|c|c|}
\hline ريزّهى سـدىى & دووبارهبونهوه & هوَكارى بهكارهينانى تقوركوَمهالايهتيهكان \\
\hline$\%$ \%r & 79 & دهستكهوتنى زانيارى بو كارى روزّنامهنوسى \\
\hline$\% 1 \cdot, r$ & m & يهاهيوهندى له گَل هاوركّ و خزم \\
\hline$\% \vee, \varepsilon$ & rt & يِِِردنهواى كاتهكانم و كاتبهسهربردن \\
\hline$\% \backslash r, \varepsilon$ & rV & عاكَهداربوون له بريارهكانى حكومـهت \\
\hline$\%$ & $\varepsilon$. & زانيارى لهسار جيهان و هـوالهكانى \\
\hline$\% \backslash r, 7$ & rی & دهستكهوتنى زانيارى لهسهر ثايروّسى كوَرونا كوثيد19 \\
\hline$\%$ & . & 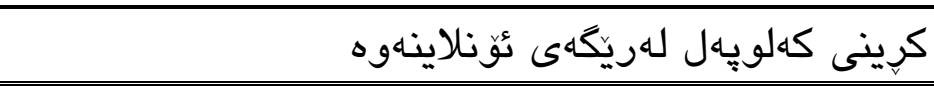 \\
\hline$\% \backslash 1, \varepsilon$ & $r \varepsilon$ & يَهيوهنديكردن به دهزكاكهم \\
\hline$\% 9,7$ & rq & عاكَداربوون له بريارهكانى تايبهت به روزنامهنووسان \\
\hline$\% 1 \ldots$ & $r \cdot$. & 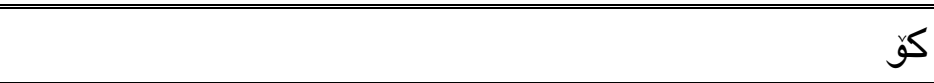 \\
\hline
\end{tabular}

مـابهاستى بهكارهينان يهكيكه لهو زانياريانهى كه رهفتارى بهكارهينانى بهكارهيناهرانى سوّشيال ميديا دهردهخات،بوّيه

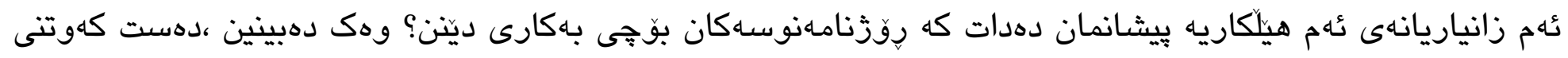

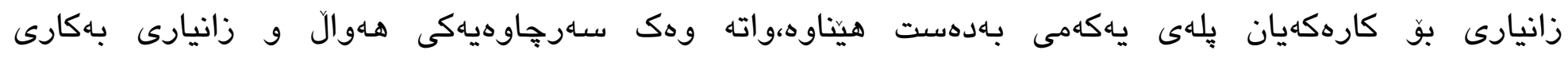

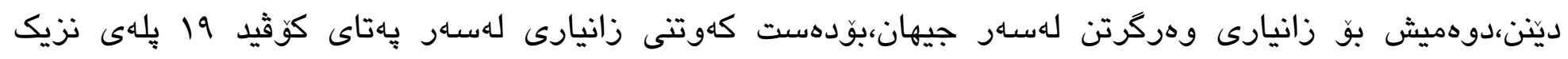

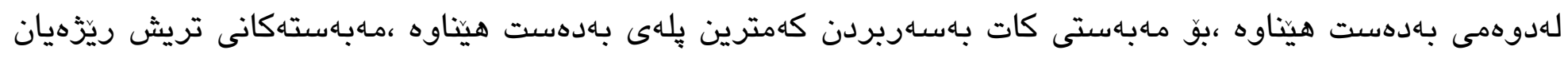

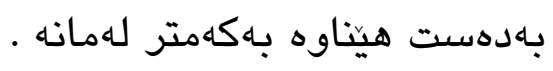


ا-بهكارهينانى سوّشيالَ ميديا لاى روّزنامهنوسان مهبهاسته سهرهكيهكهى بوّ دهست خستنى هـوال و زانياريه ،واته وهك سهارجاوهى هـهوال و دهستخستنى زانيارى بهكارى دينّن.

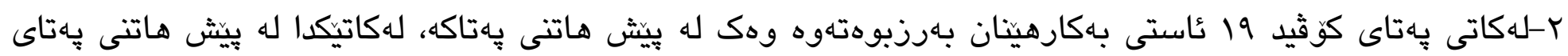

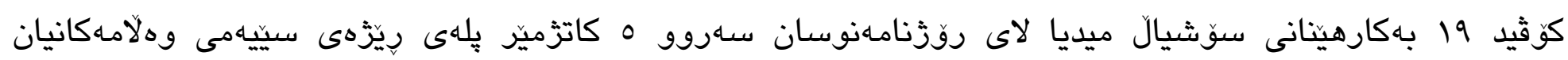

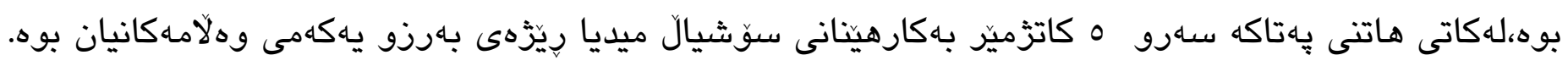

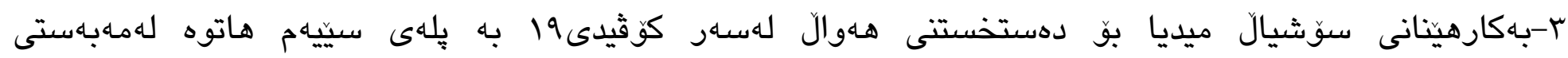

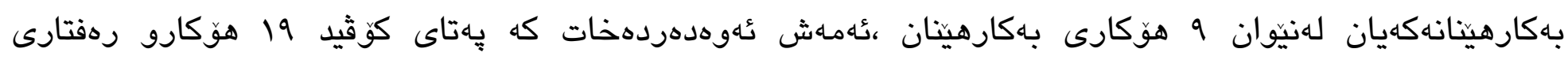

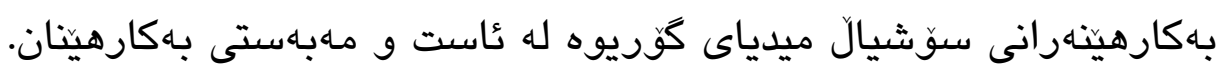

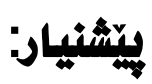

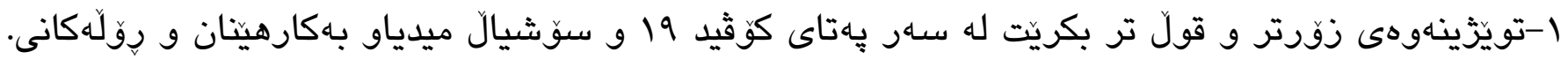




\title{
The Impact of COVID- 19 on Social media user behavior and their usage level: The Kurdish Journalist as a Case
}

\author{
Nazakat Hussein Hama saeed \\ Media department, College of Humanities, University of Sulaimani, Sulaimani, Kurdistan Region, \\ Iraq. \\ E-mail: nazakat.hamasaeed@univsul.edu.iq

\section{Hakim Othman Hameed} \\ Technical media department, Technical college of Administration, Sulaimani Polytechnic \\ University, Sulaimani, Kurdistan Region, Iraq. \\ E-mail: hakim.othman@spu.edu.iq
}

\begin{abstract}
:
This study relies on an online questionnaire survey paper, The aim of the study is to Carry out that during coronavirus and lockdown which causes people to stay at home and prevent them to get outside. "Who lost their jobs temporarily because of covid-19?" how impacted on social media user behave and their level of using .Dose being online for most of the aspect of life made journalists to use social media more than ever before. This paper focused on Journalists, because they are more intelligent to use social media and much more need to use social media regarding their jobs. For this purpose, this paper use survey method to collect data sample size which is 101 journalists

101 form being returned and responded by the Journalists from all of Kurdistan Region governess, and all type of media organization such as printer, digital and broadcast media. So that gain the answer, do the Journalist behave and their level of using social media being changed when compared coronaviruses time and before coming this crisis .
\end{abstract}

Keywords: COVID-19, Behavior ,Social Media, Journalist. 


\section{سلرجهاودكان:}

Ahmed,R.1. (2011)Social Media Marketing. Information Resources Management Association(USA).

Alex Gevers (2020) Coronavirus pandemic and online behavioural shifts. [Online] Available from: https://www.comscore.com/Insights/Blog/Coronavirus-pandemic-and-online-behaviouralshifts?fbclid=IwAR0hefTna9wOI6ukJbrHBW5ya9zefNWA1A3LsuJLPhjkaSeqZgnRzBxTD0Y . (Accessed: 10 March 2020).

Amy Watson (2020), Consuming media at home due to the coronavirus worldwide, by country.[Online] Available from: https://www.statista.com/statistics/1106498/home-mediaconsumption-coronavirus-worldwide-by-country/ (Accessed: 4April 2020).

Anneliese D. Emilie K., Raman P., Annelies W., Heidi L. (2000) The pandemic of social media panic travels faster than the COVID-19 outbreak. Centre Virchow-Villerme, Paris, France.

Barbie Zelizer(2020), Definitions of Journalism. DEPARTMENTAL PAPERS (ASC).

Bryan Segal (2020) Coronavirus Crisis is Dramatically Impacting Digital Media Consumption in Canada. [Online] Available from:https://www.comscore.com/Insights/Blog/Coronavirus-Crisis-isDramatically-Impacting-Digital-Media-Consumption-in-

Canada?fbclid=IwAR3FT8LzuJgB_wn3kGDGDs1NdSncOhApIlEIbLQmykssnnG2la1QwnFV-0w. (Accessed: 28 March 2020).

Digital Information World (2020) The Coronviruos PandamicWill increase Social media Usage. [Online] Available from:https://www.digitalinformationworld.com/2020/03/66-percent-of- 
consumers-expect-their-social-media-consumption-to-increase-during-coronavirusconfinement.html?fbclid=IwAR3FT8LzuJgB_wn3kGDGDs1NdSncOhApIlEIbLQmykssnnG2la1Q wnFV-0w (Accessed: 3March 2020).

James Seligman(2020) MARKETING IMPLICATIONS AND RESPONSE TO THE.[Online] Available from:

https://www.researchgate.net/publication/339948474_MARKETING_AND_RESPONSE_TO_THE _COVID_19_VIRUS(Accessed: 18April 2020).

Firdous,A.Sumesh,S. Dadwal,N.Vipin,K. (2018) Social Media Marketing. Hershey, Pa : Business Science.

GlobeNewswire (2020)66\% of Social Media Consumers Expect Their Social Media Consumption to Increase During Coronavirus Confinement. [Online] Available from:

https://finance.yahoo.com/news/66-social-media-consumers-expect-183010569.html . (Accessed: 10 March 2020).

Said Nadeem (2020),CORONAVIRUS COVID-19: AVAILABLE FREE LITERATURE PROVIDED BY VARIOUS COMPANIES, JOURNALS AND ORGANIZATIONS AROUND THE WORLD JOURNAL OF ONGOING CHEMICAL RESEARCH.[Online] Available from: Available from: (Accessed: 15April 2020).

مريم نريمان نومار (2012) استخدام مو اقع الثبكات الاجنماعية وتأثيره في العلاقات الاجتماعية در اسة عينة من مستخدمي موقع

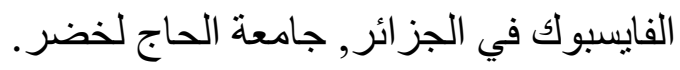

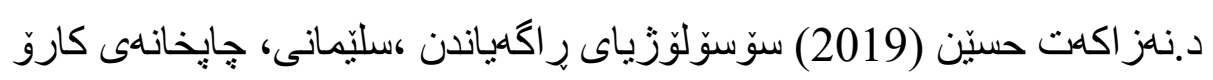

